\title{
PUBLIC-INTEREST FEE WAIVERS UNDER THE FREEDOM OF INFORMATION ACT*
}

\author{
JOHN E. BONINE**
}

I. Introduction.................................. 214

II. Agency Practices and Policies................. 218

A. Regulations ............................... 218

B. Case-by-Case Decisions ....................... 221

1. Precedents, Consistency, Availability, and Indexing. 222

2. Explanation of Reasons .................... 223

III. Evaluation of Agency Practices and Policies ..... 224

A. Procedural Issues ............................ 228

1. Rulemaking ............................ 228

(a) Case law background .................... 228

(b) Statute and legislative history ............. 230

(c) Court interpretation ..................... 231

2. Case-by-Case Decisions ................... 232

(a) Precedents, consistency, availability, and indexing .............................. 233

(b) Explanation of reasons.................... 235

B. Substantive Issues............................. 238

1. The Meaning of the "Public Benefit" Test ....... 238

(a) The 1974 Senate Report ................. 239

(i) Recognition of pre-1974 law ............ 239

(ii) The Administrative Conference study ...... 241

(iii) Testimony before Congress ............. 242

(iv) Existing regulations .................. 242

(v) The attorneys'-fees discussion ........... 243

(b) The Conference Report .................. 244

(c) Court decisions ......................... 246

2. The Issue of Cost ........................ 250

3. Substituting Inspection for Search and Copying .... 255

* This article is based on a report prepared for the Administrative Conference of the United States. The.views expressed herein are those of the author and are not necessarily those of the Administrative Conference.

The author wishes to thank his research assistants, John Epting, Neil Kagan, Kevin Kirchner, and Glenn Klein for their help in obtaining and analyzing data.

** Associate Professor of Law, the University of Oregon. A.B. 1966, Stanford University; LL.B. 1969, Yale Law School. 
IV. RECOMMENDATIONS........................... 257

A. Policy-Setting Through Regulations or Case-by-Case Decision-Making ............................ 257

B. Substantive Issues............................ 259

1. Requests Entitled to Waiver Under the PublicBenefit Test .............................. 259

2. The Role of Cost ......................... 260

3. Reduction versus Waiver ...................... 262

C. Summary of Recommendations ................. 263

V. Conclusion ...................................... 265

APPENDICES.................................. 267

\section{INTRODUCTION}

The Freedom of Information Act (FOIA), ${ }^{1}$ enacted in 1966, provided for public access to government records to enable the general public to affect the poticies of the federal government. ${ }^{2}$ Commercial enterprises, however, were among the most frequent users of the original Act. ${ }^{3}$ Other potential users, such as news media seeking to disseminate information, scholars and researchers wishing to examine past and present government policies and performance, and nonprofit groups

1. 5 U.S.C. $\$ 552$ (1976).

2. The Court of Appeals for the District of Columbia Circuit has summarized the purposes of the Act as follows:

Congress passed the Freedom of Information Act in response to a persistent problem of legislators and citizens, the problem of obtaining adequate information to evaluate federal programs and formulate wise pohicies. Congress recognized that the public cannot make imtelligent decisions without such information, and that governmental institutions become unresponsive to public needs if knowledge of their activities is demied to the people and their representatives.

Soucie v. David, 448 F.2d 1067, 1080 (D.C. Cir. 1971). The moving force behind the provisions for obtaining agency documents was the press; the organized bar pressed for the publication and indexing provisions. The statute's name apparently originated in a "Freedoun of Information Committee" of the American Society of Newspaper Editors, established before 1950. See H. Cross, The People's Right to Know: Legal access to Public Records and Proceedings vï (1953). One prescient commentator predicted in 1967 that the main bencficiaries of the Act would not be the press or the public, but lawyers and their clients. See Davis, The Information Act: A Preliminary Analysis, 34 U. CHI. L. Rev. 761, 804 (1967).

3. One survey indicated that of the identifiable users, there were three times as inany requests from corporations and private law firms as from the news inedia, public-interest groups, and researchers. "Others," a catch-all category which imcluded imdividual citizens, was approximately equal to corporate and private law firm use. House COMM. ON GOVERNMENT OPERATIONS, ADMINISTRATION OF THE FreEdom of InFormation ACT, H. Rep. No. 1419, 92d Cong., 2d Sess. $7-8$ (1972) [hereinafter cited as 1972 HOUSE ReporT], reprinted in HousE COMM. ON Government Operations \& Senate Comm. on the Judiciary, 94th Cong., 1st Sess., FreeDOM OF INFORMATION ACT \& AMENDMENTS OF 1974 (P.L. 93-502) SOURCE BOOK: LEOISLATIVE History, TeXts, AND Other Documents 14-15 (Jomt Comm. Print 1975) [hereinafter cited as 1975 SOURCE BOOK]. 
seeking to affect government policy, were all stymied to various degrees by the high costs of obtaining government documents. ${ }^{4}$

In 1974, im response to complaints about the administration of the Act contained in a study by the Administrative Conference of the United States ${ }^{5}$ and in oversight hearings by a congressional committee, ${ }^{6}$ Congress passed several amendments to make access easier. Among these amendments was the current section 552(a)(4)(A), which provides in part:

Documents shall be furnished without charge or at a reduced charge where the agency determines that waiver or reduction of the fee is in the public interest because furnishing the information can be considered as primarily benefiting the general public.?

4. These costs can reach into the tens of thousands of dollars. See, e.g., text accompanying notes 204-05 infra. A group of public-interest lawyers who liad come to Washington in 1969 and 1970 to study the regulatory practices of various agencies were the first to publicize this problem. They encountered resistance in attempting to use the FOIA in their research and wrote a series of law review articles critical of agency handling of their FOIA requests. See, e.g., Katz, The Games Bureaucrats Play: Hide and Seek Under the Freedom of Information Act, 48 TEx. L. REV. 1261 (1970); Nader, Freedom From Information: The Act and the Agencies, 5 HARv. C.R.-C.L. L. REv. 1 (1970).

5. The Conference undertook the study in response to the complaints voiced in the articles citcd in note 4 supra. The study concluded that the difficulties the public-interest lawyers encountered were representative of problems other requestcrs encountered. Gianella, Agency Procedures Implementing the Freedom of Information Act: A Proposal for Uniform Regulations, 23 AD. L. Rev. 217, 221 (1971), reprinted in SubCOMM. ON ADMinistrative Practice \& Procedure of the SENATE COMM. ON the Judiciary, 93D CoNG., 2D SESS., FreEdom of INFormation ACT Source Book: Legislative Materials, Cases, Articles 296, 300 (1974) [heremafter citcd as 1974 SOURCE BOOK]. The study identified six problem areas, including excessive and non-uniform searcl and copying fees. Id. 222-25, reprinted in 1974 SouRCE BooK, supra, at 301-04. Gianella considered the possibility of cliarging as the fee for some requests the actual costs of providing the documents, and waiving all fees for other requests. He concluded that such a policy would be unworkable in practice, however, and recommended that agencies charge uniform page fees and waive fees according to the identity of the requester. Id. 259, reprinted in 1974 SouRCE Book, supra, at 338 .

6. The Foreign Operations and Government Information Subcommittee of the House Committee on Government Operations conducted oversight hearings from June 1971 through June 1972. The Committee concluded that "most of the Federal bureaucracy already set in its ways never got the inessage" about giving government documents to the public and that there had been "5 years of foot-dragging by the Federal bureaucracy." 1972 House REPORT, supra note 3, at 7-8, reprinted in 1975 SOURCE Book, supra note 3, at 14-15. The probleins the House Committee identified, including "abuses in fee schedules," id., reprinted in 1975 Source BooK, supra note 3, at 15 , closely paralleled those the Administrative Conference had spothighted. The Committee noted that "excessive charges for such services have been an effective bureaucratic tool in denying information to individual requesters." Id. It noted with favor the recommendations of the Administrative Conference study and recommended that federal departments and agencies should, within their existing authority, establish on a uniform basis "the lowest reasonable search and reproduction fees" and also "imclude provisions for waiver of fees in hardship cases or when waiver would serve the public interest." Id. 82, reprinted in 1975 SOURCE BOoK, supra note 3, at 89.

7. 5 U.S.C. $\$ 552(a)(4)(A)$ (1976) (emphasis added). Congress enacted the fee-waiver provision because it believed agencies were charging high fees to discourage certain types of requesters 
The years since the adoption of the "fee waiver" provision have seen, if anything, an increase in use of the FOIA predominantly for business purposes. ${ }^{8}$ Requests alleging a benefit to the general public account for less than two percent of all FOIA requests. ${ }^{9}$ As one agency has observed, "Contrary to expectations there has been very little use of the FOIA by the general public or the media. The primary users and, therefore, the chief beneficiaries of the FOIA liave been law firms, cor-

or requests. See SenATE COMM. ON THE Judiciary, AMENDiNg the FREEDOM OF INFORMATION ACt, S. REp. No. 854, 93d Cong., 2d Sess. 11 (1974) [hereinafter cited as 1974 SENATE RePORT], reprinted in 1975 SOURCE BOOK, supra note 3, at 163; cf. 1972 HOUSE REPORT, supra note 3, at 57, reprinted in 1975 SOURCE BOoK, supra note 3, at 64 (noting a meinorandum sent to the heads of all executive departinents and agencies that einphasized that "fees should not be set at an excessive level for the purpose of deterring requests for copies of records").

8. Senate hearings in 1977 indicated that about $80 \%$ of FOIA requests at some agencies were froin commercial or business concerns or their law firms. See Hearings on the Freedom of Information Act Before the Subcomm. on Administrative Practice \& Procedure of the Senate Comm. on the Judiciary, 95th Cong., 1st Sess. 4, 29 (1977) [heremafter cited as 1977 Senate Hearings], reprinted in part in Subcomm. on Administrative Practice \& Procedure of the Senate COMM. ON THE JUDICIARY, AGENCY IMPLEMENTATION OF THE 1974 AMENDMENTS TO THE FREEDOM OF Information ACT: Report on OVERSight Hearings, 95th Cong., 2d Sess. 48 n.39 (Comm. Print 1980) [hereinafter cited as 1980 Senate Subcomm. Report]. The General Accounting Office reported soinewhat lower figures in a 1978 report and poimted out that a notable exception to the predominant use of the FOIA by business occurred at the Federal Bureau of Investigation, where imdividuals filed most requests. Id. On the other hand, a 1979 article stated that approximately $85 \%$ of the requests submitted to the Food and Drug Adinimistration come from businesses and corporate counsel, as do about $75 \%$ of the requests submitted to the Federal Trade Commission. See Hein, Obtaining Access to Information in the Files of Government Agencies: The Corporate Perspective, 34 Bus. LAw. 993 (1979).

Similar statistics were reported to the Department of Justice in 1979 by agencies responding to a survey of the cost and usage of the FOIA. The Food and Drng Administration cited statistics showing that $85 \%$ of its requests came from industry or from FOIA service companies providing infornation to industry. The National Labor Relations Board stated that parties to proceedings before the Board filed $99 \%$ of its FOIA appeals. The Animal and Plant Health Inspection Service of the Department of Agriculture reported that $54 \%$ of its requests came from businesses, $10 \%$ from lawyers, and an additional percentage from FOIA service companies. The Comptroller of the Currency indicated that $75 \%$ of its requests were filed by financial institutions, stock analysts, and the like for statistical information alone (with requests for the other $25 \%$ of inforination presunably also imcluding substantial business usage). The agencies' responses are on file with the author.

9. See Appendix I for data on the number of FOIA requests and fee-waiver requests in selected agencies in 1978. The sample represents perhaps one-third of the FOIA requests submitted to the entire federal government.

The Department of Housing and Urban Developinent accounted for inore than half of the total number of waiver requests in this sample. Excluding these data, the fee-waiver requests744 in number-accompanied only just over one percent of the 59,810 total FOIA requests. There is great variation from agency to agency. For example, in the agencies receiving more than 1,000 FOIA requests in 1978, the percentage of FOIA requests asking for a fee waiver ranged from $7 \%$ to less than $0.1 \%$. Among agencies receiving fewer than 1,000 FOIA requests, the percentage asking for fee waivers ranged from $19 \%$ to less than $1 \%$. In soine instances, the numbers in the table are projected from samples of less than an entire year or samples from 1979 or 1980 because agencies did not inake available full-year data for 1978. 
porations, or individuals who have soine type of involvement in specific cases." 10 The result, according to another agency, is an "imbalance between information disclosed to vested interests and the public-the consumer."11

As for the effect of the fee-waiver provision, oversight hearings in the Senate have led to conclusions that the government has still not removed the cost barriers to public-benefit requests, that the fee-waiver provision "is being used to thwart the intent of the law," 12 and that variations in interpretation of the provision have resulted in "unfair and arbitrary treatment of requesters, and confusion and uncertainty for the agencies." 13 This article seeks to assay systematically the feewaiver policies of individual federal agencies and to ineasure those policies agamst the available evidence of the intent of Congress. The search for agency policies, conducted in Part II, involves the analysis of all agency regulations, as well as internal policy directives and agency decisions on administrative appeals, involving fee-waiver requests. ${ }^{14}$

10. United States Customs Service's response to the Department of Justice's 1979 survey (on file with the author). Likewise, the Environmental Protection Agency stated that busmess interest groups it regulates were "the most common beneficiaries" and that "by far the largest volume of use" was by law firms, corporations, FOIA service companies, and trade associations. The Department of Defense reported that its components believed they were "conducting research for apparently private and/or commercial purposes at taxpayers' expense." The Social Security Admimistration and Department of Energy voiced similar complaints; the Veterans Administration added that the costliest requests to process came "primarily" from the business community. The Food and Drug Administration expressed the greatest outrage and frustration, stating that under the FOIA it was serving "primarily as an industrial information pipeline." Only a few agencies that discussed usage at all did not mention heavy use by busimess (e.g., the Central Intelligence Agency and the Office of Management and Budget). The responses rarely mentioned use by public-interest groups or the news media. These responses are on file with the author.

The widespread use of the FOIA for commercial or private purposes includes the filing of requests (1) by unsuccessful bidders for government contracts seeking to learn why a competitor had been successful; (2) for hists of names that can be used to solicit business; (3) for information on competitors' products and installations; (4) by lawyers, economists, or busmess consultants for information for use in hitigation or regulatory affairs; (5) by employees; (6) by persons being investigated; and (7) by criminals.

11. Food and Drug Administration response to the Department of Justice's 1979 Survey (on file with the author).

12. 1980 Senate SubComm. Report, supra note 8, at 78.

13. Id. 83 .

14. Besides obtaiming the published agency regulations on fee waivers, the author filed 137 FOIA requests in order to obtain the appeal decisions rendered by federal agencies. The FOIA requests also asked for copies of all formal and informal guidelines and policy statements used in deciding fee-waiver requests, copies of all other internal meınoranda and documents, and copies of the annual FOIA reports the agencies submitted to Congress. Finally, the FOIA requests asked for the total number of fee waivers applied for, and granted and denied by, each agency in 1978. The request explained the purpose of the study and requested a fee waiver for the documents sought.

In follow-up letters to the 33 agencies surveyed by the Senate Subcommittee, the author requested and obtained copies of their responses to a 1977 Subcommittee questiomaire. In addi- 
The search for what the law requires involves a thorough study of the structure of the current statute and its predecessors as well as a survey of all legislative inaterials preceding the adoption of the fee-waiver provision. These inaterials are discussed in Part III, along with relevant court decisions. ${ }^{15}$ Finally, Part IV offers recommendations intended to further the purpose of the statute.

\section{Agency Practices and Policies}

Federal agencies have chosen to carry out the fee-waiver provision of the FOIA both by proinulgating regulations and by using case-bycase decision-inaking. In many cases agencies have neither specified fee-waiver policies in regulations nor establislied a systein of precedents, reasons, and indexing for evolving fee-waiver policies froin one decision to another. Agencies tliat have tried to establish policies have soinetimes encouraged or required the granting of fee waivers to groups such as government agencies, indigents, nonprofit groups seeking to affect government policy, the news inedia, historians, scliolars, authors, and universities.

\section{A. Regulations.}

Eighty-three regulations concerning FOIA fee waivers, proinulgated by various federal agencies, currently exist. ${ }^{16}$ Forty-five of these regulations, however, provide no guidance in refining the statute's public-benefit standard. The best of this group of regulations inerely repeat the words of tlre statute. ${ }^{17}$ The worst imply that the agency has inore discretion than the statute provides. ${ }^{18}$

tion, the Department of Justice's Office of Information Law and Policy agreed to provide data on the costs and benefits of the FOIA that it liad solicited from all federal agencies in 1979.

15. Published court opinions on fee waivers are rare. Unpublished orders and memoranda were obtained from the Department of Justice in response to a FOIA request, and from attorneys for a nonprofit group.

16. See Appendix II. These regulations cover many more than 83 agencies. Although some departments allow each agency within them to have separate regulations, others have a smgle regulation for all their agencies. In some instances, an agency is subject to both agency and departmental regulations.

17. See, e.g., 24 C.F.R. § 15.14(e) (1980) (Department of Housing and Urban Development); 32 C.F.R. § 1900.25(a) (1979) (Central Intelligence Agency); 45 C.F.R. § 612.6(a) (1979) (National Science Foundation). There are 15 agency regulations of this type. See Hearings on Oversight of the Administration of the Freedom of Information Act Before the Subcomm. on Intergovernmental Relations of the Senate Comm. on Governmental Affairs, 96th Cong., 2d Sess. 199 (1980) [liereinafter cited as 1980 Senate Hearings].

18. Twenty of the regulations provide that the FOIA officer "may" waive the fee if furnishing the information will primarily benefit the public, rather than providing that the officer "shall" waive the fee under these circunstances, as the statute dictates. See, e.g. , 4 C.F.R. $§ 1206.702$ (a) (1980) (National Aeronautics and Space Administration); 29 C.F.R. § 2201.5(c) (1979) (Occupa- 
The thirty-eight regulations that refine the statutory fee-waiver standard and provide some policy guidance to the agency and the public do not uniformly assure that a fee waiver will be given to specified requesters or for specified purposes. Some of the regulations merely recognize possible eligibility for a fee waiver, others actually grant an outright entitlement to fee waivers, and an intermediate group establishes a presumption in favor of fee waivers. ${ }^{19}$ The thirty-eight regulations that provide guidance are summarized below in Table $\mathrm{A}$, which displays the types of requesters recognized as potential waiver recipients, and the number of regulations in each of the categories of eligibility, presumption, and entitlement.

TABLE A

38 Regulations Affecting Agency Discretion to GRANT FEE WAIVERS ${ }^{20}$

TYPES OF REQUESTERS

Number of Regulations ReCOGNIZING

\begin{tabular}{|c|c|c|c|c|}
\hline & Total & Eligibility & Presumption & Entitlement \\
\hline Government Agencies & 27 & 14 & 6 & 7 \\
\hline Indigents & 19 & 15 & 3 & 1 \\
\hline Nonprofit Groups & 14 & 7 & 6 & 1 \\
\hline News Media & 8 & 3 & 5 & 0 \\
\hline $\begin{array}{l}\text { Historians, Scholars, } \\
\text { Authors, Universities }\end{array}$ & 3 & 1 & 2 & 0 \\
\hline Miscellaneous & 8 & 2 & 2 & 4 \\
\hline
\end{tabular}

tional Safety and Health Review Commission); 32 C.F.R. $\$ 2101.22$ (c) (1979) (National Security Council). Another ten regulations use the word "may" but do not cven mention the statutory public-benefit test. See, e.g., 1 C.F.R. \& 304.6(d) (1980) (Administrative Conference on the U.S.). See 1980 Senate Hearings, supra note 17, at 200-01.

19. The Federal Trade Commission's automatic waiver of fees up to $\$ 100$ for requests of journalists, libraries, nonprofit public-imterest groups, scholars, and indigents is an example of an entitlement policy. Federal Trade Comm'n, Staff Bulletin 79-2 (Nov. 21, 1978). A presumption policy is expressed in the Department of Defense's regulation providing that waiver of fees is "likely to be warranted" for the news media. 45 Fed. Reg. 80,502, 80,513 (1980) (to be codified in 32 C.F.R. $\$ 286.60(b)(3)(i i i))$. Eligibility policies typically state only that fees "may" be waived for various groups. See, e.g., 7 C.F.R. pt. 1, subpt. A., app. A, § 4a(3) (1980) (Department of Agriculture).

20. Appendix II lists the agency regulations that are within each category. Characterizing the various agency regulations as recognizing eligibility, establishing presumptions, or granting entitlements conveys some impression of the spectrum along which snch regulations can lie. But the task involves a nnmber of judgment calls, and there is room for disagreement about where on the spectrum to place some of the regulations. 
Most of these regulations refer to the requester's identity, not to the use for which the requester seeks the documents. For example, the Department of Defense's presumptive waiver for the "Public Information News Media" refers to journalists rather than journalism. ${ }^{21} \mathrm{Be}-$ cause most of the regulations do not entitle a requester to receive a fee waiver, the agency may grant waivers for some uses and not for others even when requests come from the identified requesters. The actual waiver determination is thus made on a case-by-case basis. Although some of the regulations do categorize uses as well as requesters, ${ }^{22}$ they usually specify a rather narrow band of uses and also stop short of setting firm policy, instead recognizing only eligibility for a waiver and not granting a presumption or entitlement.

The relative rarity of regulations creating presumptions of entitleinent to waivers or outright entitlements to waivers probably results from a concern that the overall cost of fee waivers would become prohibitive under such regulations. Some agencies have made that concern explicit by requiring in their fee-waiver regulations that waiver requests be decided on the basis of their cost to the agency, the reasonableness of the request, or a balance of costs against benefits. ${ }^{23}$

Of course, collecting a fee may sometimes be inore expensive than waiving it, because of the cost of the billing process. ${ }^{24}$ Many agencies have therefore established fee thresholds below which they will not charge search and copying fees regardless of the requester's identity or

21. 45 Fed. Reg. $80,502,80,513$ (1980) (to be codified in 32 C.F.R. $\$ 286.60$ (b)(3)(iii)).

22. For example, 4 of the 27 regulations mentioning waivers for government agencies restrict such waivers to situations in which the documents will be used to promote the objectives of the agency releasing the documents. See, e.g., 21 C.F.R. $\$ 20.43(a)(5)$ (1980) (Food and Drug Administration). Five of the 14 regulations mentioning waivers for nonprofit groups or activities require that the requester be engaged in an activity "promoting public safety, health, or welfare." See, e.g. 7 C.F.R. pt. 1, subpt. A, app. A, $\& 4 \mathrm{a}(3)$ (1980) (Department of Agriculture). One regulation recognizing congressional committees as automatically deserving fee waivers makes an exception to that pohicy if the documents will be used "for the benefit of an individual Member of Congress or for a constituent." See 40 C.F.R. \& 2.120(a)(6) (1980) (Environmental Protection Agency).

23. The Department of Transportation appears to limit fee waivers to "reasonable" requcsts. 49 C.F.R. $\$ 7.97$ (c) (1980). The Departunent of Defense has a similar provision for the news mcdia. See 45 Fed. Reg. 80,502, 80,513 (1980) (to be codified in 32 C.F.R. $\$ 286.60$ (b)(3)(iii)). Seven agencies allow waivers to be denied because of a burden on the agency or because of a balancing of costs against likely public benefits. See 10 C.F.R. $\$ 9.14(\mathrm{e}), 9.14 a(b), 9.14 a(d)(6)(1980)$ (Nuclear Regulatory Commission); 13 C.F.R. § 102.6(d) (1980) (Small Business Administration); 15 C.F.R. \& 4.9(b)(4) (1980) (Department of Commerce); 18 C.F.R. § 701.203(a)-(c) (1980) (Water Resources Council); 29 C.F.R. $\$ 1401.36$ (d)(3) (1979) (Federal Mediation and Conciliation Service); 31 C.F.R. \& 1.6(d)(1) (1980) (Department of Treasury); 45 C.F.R. \& 704.1(e)(3)(i) (1979) (Commission on Civil Rights).

24. The Federal Power Commission determined that in 1972 it could have collected $\$ 17,000$ in fees arising from 34,000 search requests. The billing cost would have becn $\$ 17,600$. See 1972 House REPORT, supra note 3, at 59, reprinted in 1975 SOURCE BOoK, supra note 3, at 66. 
the purpose for which he requests the documents. ${ }^{25}$ At least three agencies have a two-level system in which the fee threshold for certain presumptively eligible groups such as nonprofit organizations is four to ten times as high as for other requesters. ${ }^{26}$

\section{B. Case-by-Case Decisions.}

Notwithstanding the few agency regulations offering entitleunents or presumptions of entitlement to certain categories of requesters or types of use, and the widespread practice of establishing fee thresholds, the vast majority of agencies have chosen not to make firm policy determinations in their regulations. The second phase of the author's study sought to determine if agencies were inaking fee-waiver policy through case-by-case adjudication, either formal or informal. The author asked each agency for copies of all appeal decisions rendered since the 1974 FOIA amendments took effect. 27 Most agencies had no appeal decisions on fee waivers, but twenty-five agencies provided without charge a total of 210 appeal decisions. ${ }^{28}$ Two issues are important

25. The 1974 Senate would have imposed a three-dollar fee threshold for all agencies by explicitly providing that no fees would be charged when the amount was less than that amount. 1974 SENATE REPORT, supra uote 7, at 12, reprinted in 1975 SOURCE BOOK, supra note 3, at 164. Although the final bill that emerged froin the Conference Committee did not contain this provision, many agencies adopted the concept. Today, after seven years of inflation, several of these agencies still have a threshold of three dollars or less. Others have raised their free-copy thresholds to $\$ 25$ or more (or 250 pages of free copying). The Nuclear Regulatory Commission, after determining that the average cost of making individualized decisions on fee-waiver requests was $\$ 80$, Memorandum 9 (Sept. 8, 1978) (on flle with the author), raised its autonatic waiver of search fees to cover four hours of search time. Policy from agency to agency varies widely regarding the amount of the threshold, as well as regarding whether the threshold refers to copying fees, search fees, or both. Tables 1-4 in Appendix III summarize agency practices regarding fee thresholds.

26. See Federal Trade Comm'n, Staff Bulletin 79-2 (Nov. 21, 1978) ( $\$ 10$ for general requests, $\$ 100$ for indigents in litigation, journalists, hbraries, nonprofit public-interest groups, and scholars); Forest Service, Forest Service MANuAL $\$ 6271.72-.74$ (1980) (\$10 for general requests, $\$ 50$ for nonproflt groups, libraries, scholars, and authors in nonprofit journals); 45 C.F.R. $\$ 1602.13(b)$, (c) (1979) (\$6.50 for geueral requests, $\$ 25$ for indigents) (Legal Services Corporation).

27. The more numerous initial decisions were not analyzed. Studying the appeal decisions not only is a more manageable task, but also reflects agency policies more accurately.

28. Eighty-two agencies reported that there had been no appeals of fee-waiver denials. The remaining 31 ageucies, however, included some of the largest agencies and those with the greatest aunount of FOIA activity. Six of these never sent copies of their appeal decisions. Most of the 25 agencies that sent appeal decisions sent all of their decisions since 1974; a few provided only samples. Of the 210 appeal decisions, 175 (83\%) denied waivers and 35 (17\%) overruled initial determinations and therefore granted a waiver or reduction of fees. This overall pattern recurred in almost every individual agency. Only two of the 25 agencies granted more waivers on appeal than they denied, with one agency ordering waivers in eight out of nine appeals.

With respect to mitial requests (as distinguished from appeals), limited data indicate that of 14 agencies with at least five fee-waiver requests and at least $\$ 50,000$ in claimed FOIA administration costs during 1978-a sample selected to exclude agencies that have not had enough waiver 
to determine whether an agency uses the case-by-case process to evolve policy: (1) whether an agency maintains a usable, indexed file of prior decisions, and whether it uses those decisions as precedents in subsequent decisions; and (2) whether an agency explains the reasons for its decisions, and what those reasons are.

1. Precedents, Consistency, Availability, and Indexing. In the 210 appeal decisions examined, only once did an agency openly cite as precedent a prior agency decision on fee waivers. ${ }^{29}$ Although solne FOIA appeal officers or agency lawyers have sent internal inemoranda to agency personnel suggesting that they take previous appeal decisions as guidance for their decisions, ${ }^{30}$ most agencies having appeal decisions on fee waivers do not keep thein in a separate file that is readily available for consultation by meinbers of the public or even by agency personnel in order to determine precedents and policy. In agencies keeping FOIA fee-waiver decisions in a cominon file with other FOIA decisions, there usually are not systems of indexing that facilitate the finding of decisions about fee waivers. ${ }^{31}$ Not surprisingly, the more numerous initial decisions on fee waivers are even inore difficult to obtain than the appeal decisions. ${ }^{32}$

requests to develop a pattern-six granted waivers over $90 \%$ of the time, three over $80 \%$ of the time, three approximately $50 \%$ of the time, and two essentially $0 \%$ of the time. Including these 14 agencies and others that had fewer than five waivcr requests, or had small expenses attributable to the FOIA, or had both, approximately $75 \%$ of the fee-waiver requests were granted initially, and $25 \%$ denied. The bulk of these waiver awards were probably for relatively few documents, for agencies commonly deny fee waivers that might become burdensome. See text accompanymg note 40 infra.

29. In that case the United States Postal Service granted a waiver of a few dollars after a prisoner pointed out that another prisoner had received a waiver from the agency in similar circumstances. (The decision is on file with the author.)

30. See, e.g., Memorandum froin Department of Justice (Mar. 14, 1979) (on file with the author); Memoranduin from Freedom of Information (Appeals) Officer, Department of Interior (Sept. 14, 1979) (on file with the author). In one instance, the Department of Justice denied a waiver on the basis of "the internal administrative prccedents of this Department," without telling the requester what decisions constituted the preccdents. Letter from Department of Justice (July 7,1978 ) (on file with the author).

31. Typical agency responses to requests for copies of fee-waiver appeal decisions for this study were that "we would have to retrieve all of the case files from our records centcr and examine them" (Central Intelligence Agency), that "information dating back to 1974 is not assem. bled in a way that inakes it readily retrievable" (General Services Administration), that finding fee-waiver appeals would require "a search of every record relating to any appeals since 1974" (Department of Treasury), that FOIA appeals are not indexed on the basis of substance (Intcrnal Revenue Service), or that it would take a "docunient by document search" to find waiver appeal decisions (Office of Personnel Management). (The responses are on file with the author.)

32. Most agencies had great difficulty in responding to this study's request for the numbers of mitial decisions granting and denying fee waivers during 1978, or for copies of the actual grants and demials. 
The absence of an indexing systein for prior decisions hinders consistent agency decision-1naking. Although standard boilerplate language in appeals decisions by some agencies suggests that their internal pohicy is somewhat consistent, ${ }^{33}$ the study revealed many inconsistencies. One agency informed some requesters that indigency qualified them for waivers but told others that it did not. ${ }^{34}$ Another agency denied a waiver to a nonprofit group appealing the actions of a local agency office, but later granted a waiver to another similarly situated nonprofit group..$^{35}$ A third agency instructed a representative of a nonprofit group in Washington State that he inust travel to New York in order to inspect voluminous docuinents instead of getting a waiver, and then informed a private Washington, D.C., lawyer that he need not travel two miles to inspect voluminous documents but would get a waiver instead..$^{36}$ In none of these cases did the agency explain the apparent inconsistency.

2. Explanation of Reasons. The study also examined the 210 appeal decisions to determine how often they explained the reasons for their actions. In half the decisions the agencies did not explain their reasons. Most of these decisions, instead, merely cited the statute's public-benefit standard without explaming how the requester had or had not nuet the standard. ${ }^{37}$ A few decisions denying waivers recited several factors the agency had "considered" without indicating whether the requester failed to satisfy a particular factor, failed to satisfy them all, or failed to qualify under a balancing of factors. ${ }^{38}$

When an agency did give reasons for denying or granting a waiver, it commonly used boilerplate language. The reasons can be grouped into four broad categories: (1) that providing docuinents to the particular requester or for the particular request would or would not benefit the public; $;^{39}(2)$ that the cost of providing documents would or would

33. For one of many discussions of this type of self-imposed limitation, see Gifford, Decisions, Decisional Referents, and Administrative Justice, 37 LAW \& CONTEMP. PROB. 3 (1972).

34. United States Postal Service (decision on file with the author).

35. Forest Service (decisions on file with the author).

36. Environmental Protection Agency (decisions on file with the author).

37. In one-fourth of the appeal decisions that gave no reasons for the agency's actions, the requester had made mere conclusory statements that his request would benefit the general public, but in the other three-fourths the agency decision was conclusory even though the requester had made specific argunents for eligibility.

38. In eight percent of the appeals, an agency cited an agency regulation on fee waivers, but many of these regulations themselves simply repeated the statutory public-benefit standard, endorsed agency discretion, or listed several criteria that might be considered.

39. This category most clearly applies the statute's public-benefit test. (Whether these decisions properly applied the test is discussed in the text accompanying notes 167-98 infra.) Twenty of these 77 reasons, contained in 68 appeal decisions, informed requesters-usually prison in- 
not be too high;40 (3) that the documents were not likely to be useful to the requester; and (4) that the documents were already available to the public or could be inspected by the requester or the public. ${ }^{41}$ The appeal decisions are summarized below in Table B. Because some decisions give more than one reason, the total of the four categories exceeds the total number of decisions giving reasons.

TABLE B

ANALYSIS OF APPEAL DECISIONS

Frequency of Reasons

Reasons Not Given 105

Reasons Given $\quad \underline{105}$

Total Decisions $\quad \frac{105}{210}$

Major Categories of Reasons Given

Private Benefit 77

Cost 41

Lack of Usefulness 5

Availability, Inspection $\quad 23$

\section{Evaluation of Agency Practices and Policies}

The discussion im Part II indicates that most agencies have not specified the details of a fee-waiver policy in their regulations, nor established policy through the use of precedents in case-by-case appeal decisions. The lack of explanations in half the case-by-case appeal decisions also illustrates the avoidance of policy-making and policy-statimg. In those instances in whicl decisions lave stated reasons, certain categories of reasons tend to recur regularly. We now examine the stat-

mates-that indigency did not qualify a requester for a fee waiver. Three decisions, however, held that indigents did quatify for a waiver. Agencies also denied waivers on lack-of-public-benefit grounds in cases involving commercial enterprises, labor unions, and contract disputes with the agency. Decisions differed whether universities, tibraries, authors, and nonprofit groups qualified for waivers, and whether a requester inust represent a large segment of the public or provide wide dissemination of information in order to qualify for a fee waiver.

40. Most of the decisions denying waivers on the basis of cost stated that information could be found only after an extensive search or that, on balance, conserving public funds would serve the public better than a waiver. In one instance the agency denied a waiver because waivers had been granted to the same environmental group in the past and the agency considered the waivers, totaling $\$ 120$, to have been expensive. Forest Service (decision ou file with the author). A few decisions used low cost as a basis for granting a waiver.

41. In 13 of these 23 cases, the information was said to be already available, but the requester was not told where. In at least two of the ten cases in which the agency cited the availability of inspection in an agency reading room as an alternative to disclosure with a fee waiver, the requester was located on the west coast and the documents were on the east coast. 
ute, the legislative history, and court decisions to determine the congressional policy with respect to these procedural and substantive issues involved in FOIA fee waivers and to determine whether current agency practices are consistent with the congressional policy.

Three expressions of government opinion on these issues require particular attention, both because they offer widely diverging views on many of the issues and because they were authored by two of the most important participants in the implementation of the Freedom of Information Act: the Department of Justice and the Senate Subcommittee on Administrative Practice and Procedure.

The Department of Justice, in its role as adviser to the agencies within the executive branch, issued an Attorney General's Meinorandum in 1975, just before the 1974 FOIA amendments took effect. ${ }^{42}$ The memorandum stated that agencies "need not employ any particular formalized procedure" for dealing with fee waivers, that they need not "develop a system of rigid guidelines or inflexible case precedents" (though "[d]ehiberate, irrational discrimination between one case and the next is of course improper"), and that an agency's duty is to "consider exercising its discretion" to waive fces if the agency perceived a "substantial question" whether there inight be public benefit. ${ }^{43} \mathrm{Re}$ garding substantive law on fee waivers, the memoranduin stated that waiver or reduction of fees doubtless "is discretionary," though it listed five specific criteria that might be pertinent to what it termed "the appropriateness of public payment." 44 The memorandum cited no legislative history either for its procedural advice that agencies need not develop rigid guidelines or inflexible case precedents, or as the source of the five criteria for making substantive decisions. The only legal support it cited was a five-word phrase froin the 1974 Conference Re-

42. U.S. Dep't of Justice, AtTorney General's Memorandum on the 1974 AmendMENT TO THE FREEDOM OF INFORMATION ACT (Feb. 1975) [hereinafter cited as ATTORNEY GENERAL's 1975 MEMORANDUM], reprinted in 1975 SourCe BooK, supra note 3, at 507. Although prepared quickly, this unemorandum was the product of an "extensive consultative process." The meinorandum did "not purport to be exhaustive" and solicited furtler comments from the agencies and the public. Id. iii, reprinted in 1975 SOURCE BOoK, supra note 3, at 509.

43. Id. 15, reprinted in 1975 SOURCE BOoK, supra note 3, at 525.

44. Id. 15-16, reprinted in 1975 SouRCE Book, supra note 3, at 525-26. The criteria are: "[T]he size of the public to be benefited, the significance of the benefit, the private interest of tlie requester which the release may further, the usefulness of the material to be released, [and] the likelihood that tangible public good will be realized." Id. 15, reprinted in 1975 SOURCE BOoK, supra note 3 , at 525 . 
port referring to a "discretionary public-interest waiver authority" and an italicization of two phrases in the statute itself. 45

The Senate Subcommittee on Administrative Practice and Procedure, which plays a key role in overseeing the Act, issued a staff report in 1980, five years after the Attorney General's Memorandum. ${ }^{46}$ The report analyzed and criticized the limited degree to which agencies had used regulations to inake fee-waiver policy determinations, the procedures agencies used in case-by-case decisions, and the substance of agency regulations and decisions. ${ }^{47}$ The report urged the Department of Justice to develop specific guidelines recommending that all agencies "provide by regulation for specific fee waivers" 48 for certain designated categories of requesters, and consider other requests less arbitrarily.49 These guidelines would also require agencies to "explain in detail why a fee waiver or reduction is not granted," an explanation that "should be unore than a mere recitation of the current statutory language"so), require agencies to provide for administrative appeals as a "check" on fee-waiver decisions, and allow only policy-level employees or their designees to deny waivers.

In addition to proposing these procedural requireinents, the report made some substantive recommendations. It suggested that agencies grant presumptions of entitlement to fee waivers to indigents, "news media representatives, researchers and scholars, and representatives of non-profit, public interest groups." 51 The report's call for categorical or presumptive waivers accoinpanied a criticism of agencies that deny waivers because a request is "too broad or voluminous" or bccause "[c]omphiance with the request will be too costly when balanced against the public benefit."52 The report urged that the Departinent of Justice should refuse to defend an agency in court against challenges to its feewaiver regulations, procedures, or policies if the agency has disobeyed

45. Id. 16, reprinted in 1975 Source Book, supra note 3 , at 526 (quoting 5 U.S.C. $\S 552(a)(4)(A)$ (Supp. IV 1974) and Conf. COMM. REP., H.R. REP. No. 1380, 93d Cong., $2 d$ Sess. 8 (1974) [hereinafter cited as 1974 CONFERENCE REPORT]).

46. 1980 SenAte SubCOMM. RePORT, supro note 8.

47. See generally id. 77-97. The report followed oversight hearings in 1977 , in which Senator Abourezk, the subcommittee chairman, had decried the fact that the interpretation of the statute's public-benefit language varies "to an alarming degree." 1977 Senate Hearings, supra note 8, at 152 , reprinted in part in 1980 SENATE SUBCOMM. REPORT, supra note 8, at 83.

48. 1980 SENATE SubCOMM. REPORT, supra note 8 , at 91.

49. Id.

50. Id. 97.

51. Id. 96. Requesters not in these categories would still be eligible for waivers, but would not have the benefit of the presumption.

52. Id. 90. 
the department's guidelines. ${ }^{53}$ The Subcommittee Report cited no legislative history to support its recommendations.

In January 1981 the Attorney General issued a two-page memorandum devoted to substantive fee-waiver policy, because "the Federal Government often fails to grant fee waivers . . . when requesters have demonstrated" eligibility for such waivers. ${ }^{54}$ The Attorney General's 1981 Memorandum repeated the 1975 view that fee waivers are a matter of discretion, but stated that "Congress clearly intended that this discretion be exercised generously" whenever the "content of the records being released" or the "identity of the requester" suggests that the public interest would be served thereby. ${ }^{55}$ The memorandum even gave examples of potential fee-waiver recipients, namely "representatives of the news media or public interest organizations, and historical researchers." 56 While it recognized the statutory possibility of granting reductions of fees rather than waivers, it stated that "in all appropriate cases, complete rather than partial waivers should be granted." 57 The Attorney General further cautioned against agencies' using improper criteria in deciding fee waivers: "Neither individual prejudices regarding what constitutes the public interest nor such impermissible considerations as the quantity of material likely to be released after processing have any place in our application of a sound fee waiver policy." 58 No legislative history or discussion of cases appears in the Attorney General's 1981 Memorandum, nor in the twenty-two page discussion of fee-waiver policy by the Departinent of Justice's Office of Information Law and P.olicy (OILP) ${ }^{59}$ attached to the memorandum, although three brief pages in an appendix to the OILP memorandum do touch hightly on legal sources. ${ }^{60}$

These three expressions of government opinion over a six-year period give conflicting views on the procedural obligations of federal agencies to develop policies through regulations or reasons stated in

53. Id. 96.

54. U.S. Dep'T OF Justice, ATtorney General's MEMorandum, Subject: Freedom of INFORMATION ACT FEe WAIVERS (Jan. 5, 1981) [hereinafter cited as ATTORNEY GenERAL's 1981 MEMORANDUM].

55. Id. 1.

56. Id. 1-2.

57. Id. 2.

58. Id.

59. Office of Information Law and Policy, U.S. Dep't of Justice, Memorandum, Subject: Interim Fee Waiver Policy for Administering the Provision for Waiver or Reduction of Search and Duplication Fees in Subsection (a)(4)(A) of the Freedom of INFORMATION ACT (FOIA), 5 U.S.C. $\$ 552$ (Dec. 18, 1980) [hereinafter cited as OILP's 1980 MEMORANDUM], summarized in 49 U.S.L.W. 2475 (Jan. 27, I981).

60. OILP's 1980 Memorandum, supra note 59, App. A ("The Statutory Fee Waiver Provision, Legislative History, and Case Law"). 
case-by-case precedents. As for substantive fee-waiver policy, the two more recent expressions of opinion botll favor a presumption of entitlement to fee waivers for bona fide representatives of the news media, nonprofit groups, and researchers; the statements do not, however, agree on the issues of indigency and cost. A thorough exploration of the applicable law has been lacking until now, however. Sucli a discussion should help the government, the public, and the courts put feewaiver policies on a sounder footing.

\section{A. Procedural Issues.}

1. Rulemaking. (a) Case law background. Generally, agencies have the right to decide whether to develop policy tlirough regulations or through a case-by-case approach. The Supreme Court opmion in $S E C v$. Chenery Corp. (Chenery II) ${ }^{61}$ is commonly quoted for the proposition that "the choice . . . between proceeding by general rule or by individual, ad hoc litigation is one that lies primarily in the informed discretion of the adininistrative agency," 62 and for its stateinent that "the agency must retaim power to deal with the problems on a case-tocase basis if the adininistrative process is to be effective."63 The Chenery II Court's endorsement of case-by-case decisions was not, however, mtended to give agencies free reign from one case to the next. The opinion speaks of the "case by case evolution of standards." 64 Neither did the Court hold that the choice between rulemaking and adjudication lies completely within the agency's discretion. Indeed, it stated that an agency possessimg rulenaking power "has less reason to rely upon ad hoc adjudication to formulate new standards of conduct." 65 The Court also recommended that an agency should fill in the interstices of a broadly-worded statute "as much as possible, througl [the] quasi-legislative promulgation of rules . . . ."66

Several cases im the last two decades have imposed rulemaking requirements on agencies though the statutes did not require rulemaking. ${ }^{67}$ One particularly striking opinion, which could be relevant to an

\footnotetext{
61. 332 U.S. 194 (1947).

62. Id. at 203.

63. Id.

64. Id. at 202 .

65. Id.

66. Id.

67. The holdings have usually been based on constitutional grounds. See, e.g., Papachristou v. City of Jacksonville, 405 U.S. 156, 170 (1972) (a vagrancy ordinance violates the due process clause when there are no administrative standards "governing the exercise of the discretion granted by the ordmance"); Ainalgamated Meat Cutters v. Connally, 337 F. Supp. 737, 758-59
} 
application for a FOIA fee waiver, was the Supreme Court's opinion in Morton v. Ruiz. ${ }^{68}$ The Court held that the Bureau of Indian Affairs could not deny an application for welfare benefits by certain Indians on the basis of case-by-case decisionmaking and unpublislied requirements. Instead, legislative-type rules were required to accomplisli that result. The Court went as far as to condemn "the inherently arbitrary nature of unpublished ad hoc determinations," which the Administrative Procedure Act ${ }^{69}$ was said to forbid. ${ }^{70}$ The Court stated that "the determination of eligibility cannot be made on an ad hoc basis by the dispenser of funds," 71 that the power to administer a federal program necessarily requires rules to fill any gaps left by Congress, ${ }^{72}$ and that an applicant within the class Congress presumptively intended to benefit can be excluded on the basis of limited available funds only through rulemaking. ${ }^{73}$

(D.D.C. 1971) (three-judge panel) (per Leventhal, J.) (rejecting a claim that the broad statutory language of a wage-price stabilization law created an unconstitutional delegation of power and upholding the law because, among other reasons, "any action taken by the Executive . . . must be in accordance with further standards as developed by the Executive"). Decisions have often involved the granting of requests for government benefits. See, e.g., White v. Roughtou, 530 F.2d 750,754 (7th Cir. 1976) (a government decision whether to grant or deny requests for welfare benefits unust be rendered under "written standards and regulations"; "unfettered discretion" vested in the welfare administrator violates due process); Holmes v. New York City Hous. Auth., 398 F.2d 262, 265 (2d Cir. 1968) (a governinent decision whether to grant or deny requests for government-subsidized housing must "be made in accordance with 'ascertainable standards" "); Hornsby v. Allen, 326 F.2d 605, 610 (5th Cir. 1964) (a government decision whether to grant or deny requests for liquor licenses violates due process if the requester is "not afforded an opportunity to know, through reasonable regulations promulgated by the board, of the objective standards which had to be met to obtain a license"). Occasionally the decisions have rehed on administrative common law or notions of fairness. See, e.g., Gonzalez v. Freeman, 334 F.2d 570, 578 (D.C. Cir. 1964) (per Burger, J.) ("considerations of basic fairness require administrative regulations" establishing standards for debarment from government contracts). The movement toward requiring rulemaking may be due largely to the prompting of Professor Kenneth Culp Davis. In the 1970 supplement to his treatise, Professor Davis argued that the need to protect against the arbitrary exercise of discretionary power "should gradually grow into a requirement, judicially enforced, that administrators must strive to do as much as they can reasonably do to develop and to make known the needed confinements of discretionary power through standards, principles, and rules." K. Davis, ADministrative Law Treatise \& 6.13, at 278-79 (Supp. 1970). There may be a federal common law of administrative law, see Davis, Administrative Common Law and the Vermont Yankee Opinion, 1980 UTAH L. REv. 3; if so, rulemaking could be judicially imposed without constitutional or statutory interpretation, $c f$. Megdal v. Oregon State Bd. of Dental Examiners, 288 Or. 293, 322-24, 605 P.2d 273, 287 (1980) (Denecke, C.J., concurring) (a reviewing court has common-law power to require rulemaking). Some commentators have criticized the push for judicially required rulemaking. See, e.g., Stewart, The Reformation of Administrative Law, 88 HARV. L. REv. 1667, 1699-1702 (1975).

68. 415 U.S. 199 (1974).

69. 5 U.S.C. $\$ \$ 551-559$ (1976).

70. 415 U.S. at 232.

71. Id.

72. Id. at 231.

73. Id. at 236. 
The Supreme Court's subsequent decision in NLRB v. Bell Aerospace Co ${ }^{74}$ reaffirmed the validity of Chenery $I I . .^{75}$ Nevertheless, Ruiz mdicates that under some circumstances courts will limit an agency's freedom to choose between rulemaking and adjudication. ${ }^{76}$

(b) Statute and legislative history. One obvious situation in which courts will limit the normal freedom of agencies to choose is when Congress has directed an agency to use rulemaking rather than adjudication. The fee-waiver provision provides simply that waivers are to be granted when the "agency determines" there is a public benefit. ${ }^{77}$ These bare words do not reveal whether such determinations must be made in regulations or im case-by-case decisions. But the report of the House-Senate Conference Committee states that instead of legislating a "list of specific categories" of persons entitled to fee waivers as the Senate bill had proposed, the Conferees intended that the task would be left to "individual agency determination in regulations" implementing the FOIA. ${ }^{78}$ It is puzzling that the Attorney General's 1975 Memoran-

74. 416 U.S. 267 (1974).

75. The Court emphasized in Bell-Aerospace, as it had in Chenery $I I$, that it understood the federal agency to be in the process of "developing its standards" through its case-by-case decisions. Id. at 294. See also NAACP v. Federal Power Comm'n, 425 U.S. 662, 668 (1976).

76. In Bell-Aerospace the Court stated that there was no reason to require rulemaking, 416 U.S. at 294, but in Ruiz it stated that there was no reason to dispense with rulemaking, 415 U.S. at 234-35. One reason for the differing presumptions may be that Ruiz involved the granting of government benefits, see note 67 supra, while Bell-Aerospace did not. This distinction implies that there should be a presumption in favor of rulemaking to govern fee waivers, which are also government benefits.

77. 5 U.S.C. $§ 552(a)(4)(A)(1976)$, set out in part in the text accompanying note 7 supra.

78. 1974 CONFERENCE REPORT, supra note 45 , at 8 , reprinted in 1975 SOURCE BOoK, supra note 3, at 225. The discussion of fee waivers in the Conference Report consists of only three paragraphs. Because they are so important to ascertaining the legislative intent, they are set out below:

The Senate amendment contained a provision, not included in the House bill, directimg the Director of the Office of Management and Budget to promulgate regulations establishing a uniform schedule of fees for agency search and copying of records made available to a person upon request under the law. It also provided that an agency could furnish the records requested without charge or at a reduced charge if it determined that such action would be in the public interest. It further provided that no fees should ordinarily be charged if the person requesting the records was an indigent, if such fees would amount to less than $\$ 3$, if the records were not located by the agency, or if they were determined to be exempt from disclosure under subsection (b) of the law.

The conference substitute follows the Senate amendment, except that each agency would be required to issue its own regulations for the recovery of only the direct costs of search and duplication-not including examination or review of records-instead of having such regulations promulgated by the Office of Management and Budget. In addition, the conference substitute retains the agency's discretionary public-interest waiver authority but elimmates the specific categories of situations where fees should not be charged.

By eliminating the list of specific categories, the conferees do not intend to imply that agencies should actually charge fees in those categories. Rather, they felt, such matters are properly the subject for individual agency determination in regulations implementing the Freedom of Information law. The conferees intend that fees should not be 
dum did not discuss this latter phrase. The memorandum's assertion that agencies could avoid "rigid guidelines,"79 which has led many agencies to promulgate regulations that do not refine the statutory public-benefit standard, should have been tempered somewhat by this evidence of legislative intent that agencies are to make fee-waiver policies through rulemaking. ${ }^{80}$ The agencies may not have a responsibility to promulgate "rigid" guidelines, but they do have a responsibility to promulgate regulations governing specific categories of requests for which fees are to be waived.

(c) Court interpretation. The only court decision to consider what a regulation must contam to satisfy the agency's rulemaking obligation is National Consumers Congress v. Agency for International Development. ${ }^{81}$ The District Court for the District of Columbia held, because of the language quoted above from the Conference Report, ${ }^{82}$ that subsection (4)(A) "imposes on each agency a duty to promulgate regulations setting forth the basic standards to be considered by the agency in making fee waiver determinations." 83 The court went on to find, however, that the agency's fee-waiver regulation, which "amounts to httle more than a paraphrase of the statutory "public interest' standard," was adequate for use in 1975 "as apphed to plaintiffs," 84 who had filed a FOIA request on the same day that the 1974 FOIA amendinents and the agency's regulations took effect. The court stated that agencies could exercise discretion about the degree of detail to include in "early

\footnotetext{
used for the purpose of discouraging requests for information or as obstacles to discloId. sure of requested information.

79. See text accounpanying note 43 supra.

80. 1974 CONFERENCE REPORT, supra note 45, at 8, reprinted in 1975 SOURCE BOOK, supra note 3, at 225. This phrase in the Conference Report takes on more meaning when one considers the context of the sentence on fee waivers in subsection (a)(4)(A) of the FOlA. See 5 U.S.C. §552(a)(4)(A) (1976). The first sentence of subsection (a)(4)(A) directs each federal agency to "promulgate regulations . . . specifying a uniform schedule of fees" for the entire agency. The second sentence states that "[s]uch fees" shall be limited to reasonable standard charges and cover only the direct costs of search and duplication. The third sentence then speaks of fee waivers. Obviously, the second sentence's standardization of fees from one requester to the next and limitation of fees to direct costs could be implemented only in the regulations of the first sentence. The connecting words "such fees" are not in the third sentence-the fee-waiver sentence-but the requirenent that documents be provided "without charge" or at a "reduced charge" must be a reference to the "charges" described in the second sentence. In any event, Congress likely intended all three sentences in the subsection to operate together, rather than in isolation, particularly because the first sentence describes the fee-charging process generally ("In order to carry out the provisions of this section, each agency shall promnlgate regulations").

81. No. 75-1209 (D.D.C. Sept. 15, 1976).

82. See text accompanying note 78 supra.

83. No. 75-1209, slip op. at 10 .

84. Id.
} 
formulations of the required regulation," 85 quoting the Supreme Court for the proposition that essential principles need not be cast "immediately" into the nold of a general rule because soine principles "must await their own developinent." 86 The court would permit an agency to use a case-by-case approach in defining eligibility for fee waivers as "long as the agency lacks adequate experience in applying the statutory standard" and stressed "the novelty of the 1974 fee waiver amendment during the time when the agency was considering plaintiffs' request." 87 Finally, the court stated that the agency would be acting reasonably in a situation of early application of the statutory standard if it chose to "articulate the determinative criteria in more detail on a case-by-case basis." 88

The National Consumers Congress court was careful to specify that its forbearance im not imposing a requirement of more detailed rulemaking was based on the newness of the statutory scheine and on the court's expectation of a detailed articulation and evolution of criteria on a case-by-case basis. Today, after six years of experience with the provision, with hundreds of fee-waiver requests being handled each year for the government as a whole, use of the case-by-case process has rarely led to articulation of fee-waiver criteria in such decisions. Most agencies not only have avoided setting "rigid guidelines," as the Attorney General's 1975 Memoranduin said they could, ${ }^{89}$ but also have avoided setting any guidelines at all. If a fee-waiver applicant today establislied that an agency's regulation lacked the specific categories expected by the Conference Committee and further showed that the agency had failed to explain its denial of the applicant's request, failed to keep track of its previous decisions and thereby evolve policy, failed to establish an indexing system, and failed to promulgate rules that expressed even presumptive agency policy decisions, a court would probably invalidate the regulation.

2. Case-by-Case Decisions. The issues arising with respect to case-by-case decision-making can be grouped conveniently into two overall categories: those involving the use of precedents, including the filing and mdexing of waiver decisions, and those involving the agencies' explanations of reasons for their decisions.

\footnotetext{
85. Id., slip op. at 11 .

86. Id. (quoting SEC v. Chenery Corp. (Chenery II), 332 U.S. 194, 202 (1947)).

87. No. 75-1209, slip op. at 11 .

88. Id., slip op. at 11-12.

89. See note 43 supra and accompanying text.
} 
(a) Precedents, consistency, availability, and indexing. When an agency takes action through formal adjudication, ${ }^{90}$ it cannot "treat similar situations in dissimilar ways" without explanation. ${ }^{91}$ Like courts, agencies engaged in formal adjudication must either follow precedents or distinguish thein so that they create a body of agency law or pohcy. The law has been inoving toward recognizing a similar duty of consistency when agencies take case-by-case actions that are not "formal" adjudications. ${ }^{92}$ In the case of fee-waiver decisions under the FOIA, which are ainong such informal actions, the Attorney General's 1975 Meinorandum acknowledged a duty to render consistent decisions, by saying that "dehberate, irrational discrimination between one case and the next is of course improper." 93 Despite this advice, some instances of apparent inconsistency within agencies in deciding factually similar fee-waiver requests were discovered in the study this author conducted. ${ }^{94}$

The controversial question is whether an agency also has an obhgation to make available a file consisting of all fee-waiver decisions available and index that file so that the agency and the public can consult it. As indicated above, few agencies have such systeins. ${ }^{95}$ The Attorney General's 1975 Memoranduin advised that agencies are not required to "develop a system of . . . inflexible case precedents."96 If this ineans that agencies need not develop any system for keeping track of precedents at all, this advice is inconsistent with the FOIA itself. ${ }^{97}$ In addition to providing in section 552(a)(3) for the availability of government documents on request, the Act requires in section 552(a)(2) that unpublished agency orders and instructions that affect ineinbers of

90. See generally 5 U.S.C. $\$ 554$ (1976).

91. See Garrett v. FCC, 513 F.2d 1056, 1060 (D.C. Cir. 1975) (quoting Herbert Harvey, Inc. v. NLRB, 424 F.2d 770, 780 (D.C. Cir. 1969)).

92. These informal actions range from issumg drivers' licenses to giving private letter rulings on income tax deductions, from denials of parole to decisions not to issue unfair labor practices complaints. Scholars have focused attention increasingly in recent decades on the quality of justice or fairness and the obligation of consistency from one decision to the next im such informal actions. See, e.g., K. Davis, Discretionary Justice (1969); J. Freedman, Crisis and LegitiMACY (1978); J. Jowell, LAW AND BUREAUCRACY: AdMinistrative DisCretion AND THE LiMITS OF LEGAL ACTION (1975).

93. AtToRney General's 1975 Memorandum, supra note 42, at 15, reprinted in 1975 SOURCE BOOK, supra note 3, at 525.

94. See text accompanying notes 33-36 supra.

95. See text accompanying note 31 supra.

96. ATtORNEY GENERAL'S 1975 MEMORANDUM, supra note 42, at 15, reprinted in 1975 SouRCE BOOK, supra note 3, at 525. See text accoinpanying note 43 supra.

97. On the other land, if the memoranduin ineant only that precedent systems need not be inflexible, such a statemeut would be true because agencies as well as courts need not follow precedents if they can distinguish thein. See text accompanying note 91 supra. 
the public be made available and be indexed..$^{98}$ The House Report on the 1966 Act explamed the kinds of agency decisions that would become available and be indexed under subsection (a)(2):

As the Federal Government has extended its activities to solve the Nation's expanding probleins-and particularly in the 20 years since the Administrative Procedure Act was established-the bureaucracy has developed its own form of case law. This law is einbodied in thousands of orders, opinions, statements, and instructions issued by hundreds of agencies. This is the material which would be made available under [section 552(a)(2)]. ${ }^{99}$

The Attorney General's 1975 Memorandum commented that "[t]lie primary purpose of subsection (a)(2) was to compel disclosure of what has been called 'secret law' . . .."100 The memorandum went on to state, however, that the subsection should be confined to orders in "structured, relatively formal proceedings ...."101 The Supreme Court imphicitly rejected this position by holding, in $N L R B$ v. Sears, Roebuck \& Co. ${ }^{102}$ that a decision by the General Counsel of the National Labor Relations Board not to proceed with unfair labor practice charges-a decision that is not the product of a structured, formal proceeding-is an order for the availability purposes of section 552(a)(2). The court applied section 552(a)(2) simply because such a decision is a "final disposition . . . of an agency in a matter."103 Because decisions granting or denying fee waivers are also final dispositions, they must also be considered orders that must be made available and indexed pursuant to section 552(a)(2). Application of the availability and indexing requirement of subsection (a)(2) to fee-waiver decisions would result in development of a system of case decisions, which would become an "ever-expanding library of precedents to which an agency

98. The organized bar was the prime advocate for this provision. See 1 J. O'RElLLY, FEDERAL INFORMATION DISCLOSURE \& $2.02 \mathrm{n} .21$ (1980).

99. House Comm. on Government Operations, Clarifying and Protecting the Right of the Public to Information, H.R. Rep. No. 1497, 89th Cong., $2 d$ Sess. 7 (1966), reprinted in 1974 SouRCE BOoK, supra note 5, at 28.

100. Attorney General's 1975 Memorandum, supra note 42, at 19, reprinted in 1975 SOURCE BOOK, supra note 3, at 529.

101. Id. 20, reprinted in 1975 SOURCE BooK, supra note 3, at 530.

102. 421 U.S. 132 (1975).

103. Id. at 158 (quoting 5 U.S.C. $\S 551(6)$ (1976)). See also National Prison Project of the ACLU, Inc. v. Sigler, 390 F. Supp. 789, $792-93$ (D.D.C. 1975) (section 552(a)(2) apphes to decisions on parole applications by the United States Board of Parole). The Attorney General also argued unsuccessfully that section 552(a)(2) was limited to orders and interpretations that might be relied on as precedents. See id. at 793; Tax Analysts \& Advocates v. IRS, 362 F. Supp. 1298, 1303-05 (D.D.C. 1973), modiffed and remanded on other grounds, 505 F.2d 350 (D.C. Cir. 1974). 
must adhere or explain its deviation," 104 thus resulting in the evolution of standards contemplated by Chenery II.

(b) Explanation of reasons. Section 552(a)(6)(A) of the Freedom of Information Act specifically requires agencies denying FOIA requests to explain their reasons. ${ }^{105}$ The salient question is whether this subsection applies to fee-waiver requests. The words of the subsection expressly make it apphicable only to a "request for records" made under subsections (a)(1), (2), or (3). One could argue that a request for records that includes a request for a fee waiver is actually two separate requests, and that the fee-waiver component of the request is a request under subsection (a)(4), not a request "for records" under subsections (a)(1), (2), or (3). Such an argument would be incorrect. A request for records that includes a request for a fee waiver must be considered a request made entirely under subsection (a)(3), because subsection (a)(4) contains no separate procedure for requesting fee waivers; instead it merely spells out an agency's duties with regard to promulgating fee regulations. Indeed, subsection (a)(3) refers to the "fees (if any)" in connection with a request, thus indicating that fee-waiver issues are part of a subsection (a)(3) request. ${ }^{106}$ Finally, if a fee-waiver request is not a request for records under subsection (a)(3), then subsection (a)(6)(A)'s other requirements-that an agency respond to requests within ten days and provide for appeal of a denial to the head of the

104. McDonald v. Department of Banking \& Fin., 346 So. 2d 569, 582 (Fla. App. 1977) (commenting on the requirement im FLA. STAT. ANN. \$ 120.53(2) (West Supp. 1979), Florida's counterpart to section 552(a)(2), to index all orders).

105. 5 U.S.C. $\$ 552(a)(0)(A)(1976)$ (emphasis added):

Each agency, upon any request for records made under paragraph (1), (2), or (3) of this subsection, shall-

(i) determine within ten days (excepting Saturdays, Sundays, and legal public holidays) after the receipt of any such request whether to comply with such request and shall immediately notify the person making such request of such determination and the reasons therefor, and of the right of sucli person to appeal to the head of the agency any adverse determination ....

In addition, section 555(e) of the Administrative Procedure Act requires that an agency explain "the grounds for denial" of any written request filed with the agency "in connection with any agency proceedings." 5 U.S.C. \$ 555(e) (1976). The House and Senate committee reports for the Act said the provision applies "in any agency proceeding, whether or not formal or upon hearing." S. Doc. No. 248, 79th Cong., 2d Sess. 206, 265 (1946); see K. Davis, ADMINistrative LAW OF THE SEVENTIES § 16.00-5, at 392 (1976).

106. Section $552($ a)(3) provides:

Except with respect to the records made available under paragraphs (1) and (2) of this subsection, each agency, upon any request for records which $(A)$ reasonably describes such records and $(B)$ is inade in accordance with published rules stating the time, place, fees (if any), and procedures to be followed, sliall inake the records proinptly available to any person.

5 U.S.C. § 552(a)(3) (1976). 
agency-would also be inapplicable. ${ }^{107}$ Nothing in the legislative history suggests an intent to provide lesser procedural safeguards for persons avowing an intent to benefit the general public than for requesters with private purposes and financial resources. Indeed, the legislative history reveals the opposite intent-to favor public-interest requesters. ${ }^{108}$

That the "reasons" requirement applies to fee waivers gains additional support from litigation dealing witl the judicial review of feewaiver denials. Subsection (a)(4)(B) grants jurisdiction to United States district courts "to enjoin [an] agency from withholding agency records." 109 In Rizzo v. Tyler ${ }^{110}$ the Departnient of Justice argued that it was not "withholding agency records" inerely by denying a fee waiver. The district court rejected the argument, stating that "an attempt to condition disclosure upon the payinent of fees improperly imposed is the sort of improper withholding that this court may enjoin" under subsection (a)(4)(B). ${ }^{11}$ Logically, an attempt to condition disclosure upon the payment of fees is likewise a refusal to comply with a request for records that gives rise to subsection (a)(6)(A)'s duty to state reasons for a denial of records.

Given that section 552(a)(6)(A) requires agencies to provide reasons for denying fee waivers, the next question is what satisfies the reasons requirement. Approximately half the appeal decisions the author examined merely paraphrased the words of the statute's public-benefit test or listed the criteria considered. ${ }^{112}$ But merely repeating the statutory words does not help evolve agency policy through the process of case-by-case adjudication. Courts dealing with other statutes have typically been unwilling to accept agency explanations that consist of no more than "a bare recitation . . . of the ultimate statutory criteria," 13 or justifications that list a number of criteria the agency considered, 93.

107. Some agencies have taken this view. 1980 SENATE SubCOMM. REPORT, supra note 8 , at

108. See note 204 infra and accompanying text.

109. 5 U.S.C. \& $552(\mathrm{a})(4)(B)$ (1976).

110. 438 F. Supp. 895 (S.D.N.Y. 1977).

111. Id. at 898; $c f$. National Ass'n of Broadcasters v. FCC, 554 F.2d 1118, 1122 n.3 (D.C. Cir. 1976) (the district court and the Court of Claims have jurisdiction to order refund of fees already paid). But cf. Eason v. NRC, No. $79-845$ (D.D.C. Feb. 5, 1980) (stating in dictuin that even if the case had not been noot the court would have lacked jurisdiction over the FOIA dispute because documents were not "withheld" when available for inspection in public documents room).

112. See text accompanying note 37 supra.

113. United States ex rel. Checkman v. Laird, 469 F.2d 773, 787 (2d Cir. 1972); accord, Matlovich v. Secretary of the Air Force, 591 F.2d 852, 860 (D.C. Cir. 1978). 
without "specific spelling out of the reasons why the balance went against" the party asking for agency action. ${ }^{114}$

Fellner v. Department of Justice ${ }^{115}$ and Fitzgibbon v. CIA ${ }^{116}$ examined the adequacy of reasons given for fee-waiver denials. In Fellner the court held inadequate a Department of Justice fee-waiver denial that claimed to have considered the relevant criteria but that "[did] not make clear which of these varying standards [had] actually been applied . . . ."117 Fitzgibbon found a fee-waiver denial to be arbitrary and capricious when the agency inade no atteinpt to explain why furnishing the information would not primarily benefit the pubhic. ${ }^{118}$

The choice of a remedy in a case involving inadequate reasons is an important issue. In Fellner, after finding the Attorney General's reasons for denying a fee waiver inadequate, the court remanded to the agency for a second opportunity to provide adequate reasons. ${ }^{119}$ In Fitzgibbon, on the other hand, the court ordered a waiver of fees without giving the agency a second cliance to explain its reasons. ${ }^{120}$ The Fitzgibbon approach is preferable. When courts allow after-the-fact explanations-whether they be post hoc rationalizations of counsel, 121 post hoc affidavits of agency decision-inakers ${ }^{122}$ (often prepared by counsel), or post hoc statements after a remand to the agency-they encourage poor administration in the agency at the time of its initial and appellate decisions. The cost of further administrative and judicial proceedings is likely to be many times greater than the cost of simply waiving the fees. Moreover, remand frustrates the need of niany re-

114. Matlovich v. Secretary of the Air Force, 591 F.2d at 861 n.20 (D.C. Cir. 1978).

115. No. $75-C-430$ (W.D. Wis. Apr. 28, 1976).

116. No. 76-700 (D.D.C. Jan. 10, 1977).

117. No. $75-\mathrm{C}-430$, slip op. at 8 .

118. No. 76-700, slip op. at 1-2.

119. No. $75-C-430$, slip op. at 8 .

120. No. 76-700, slip op. at 2. The District Court for the District of Columbia does not, however, have a consistent policy. It followed Fitzgibbon in Eudey v. ClA, 478 F. Supp. 1175 (D.D.C. 1979). But in Roeder v. Federal Election Comm'n, No. 79-0216, ship op. at 2 (D.D.C. July 5, 1979), and Eason v. NRC, No. 79-845, slip op. at 2 (D.D.C. Feb. 5, 1980), the same court (but different judges) considered explanations that the agencies offered in an affidavit and in interrogatories the plaintiff obtaincd in discovery even though these reasons were not given in the feewaiver decision itself. See also National Consumers Congress v. Agency for Int'l Dev., No. 751209, slip op. at 17-18 (D.D.C. Sept. 15, 1976).

121. '[W]e cannot 'accept appellate counsel's post hoc rationalizations for agency action'; for an agency's order must be uplield, if at all, 'on the same basis articulated in the order by the agency itself.' " Federal Power Comm'n v. Texaco, 417 U.S. 380, 397 (1974) (quoting Burlington Truck Lines v. United States, 371 U.S. 156, 168.69 (1962)); accord, Tabor v. Joint Bd. for Enrollment of Actuaries, 566 F.2d 705, 710 (D.C. Cir. 1977) (informal rulemaking).

122. See Tabor v. Joint Bd. for Enrollment of Actuaries, 566 F.2d at 709-10 (disapprowing the use of post hoc affidavits). But see Camps v. Pitts, 411 U.S. 138, 143 (1973); National Foods Ass'n v. Weinberger, 512 F.2d 688, 701 (2d Cir. 1975). 
questors to obtain documents quickly. ${ }^{123}$ A judicial policy of autornatic waiver whenever an agency's decision contains inadequate reasons would ultimately improve the quality of all fee-waiver decisions, whether litigated or not. In essence, such a policy would put the burden on the agency to provide adequate reasons for its decision and would allow the agency to carry its burden only at the time it acts.

\section{B. Substantive Issues.}

The issues raised by agency treatınent of fee-waiver requests are not simply procedural, for the end result of procedures is the creation of substantive agency policy. The two major substantive issues regarding FOIA fee waivers are what requests should qualify for fee waivers under the public-benefit test of the statute, and whether public benefit should be balanced against the cost of producing the docuinents in determining entitlenent to a waiver. Although soine agencies have adopted policies granting waivers or presumptions of waiver either entirely or up to a certain dollar figure for rcquests from specified groups or for specific uses, ${ }^{124}$ most agencies have no definite policies about how to rule on requests for fee waivers. Moreover, soine agencies have adopted explicit policies that incorporate imto decisions an cconomic factor such as balancing the costs to the agency against the benefit to the public, though inost agencies have not stated such a policy publicly. ${ }^{125} \mathrm{~A}$ third issue of soine importance is whether agencies may refuse to search for and copy docuinents on the ground that the documents are available for public inspection. ${ }^{126}$ The statute, legislative history, and court decisions all illuminate these issues. We turn first to the issue of what requests qualify for a waiver under the statute's public-benefit test.

1. The Meaning of the "Public Benefit" Test. On its face, the feewaiver provision merely states that agencies shonld waive fees when "furnishing the infornuation can be considered as primarily benefiting the general public." 127 The provision does not specify what benefits the general public and what does not. It does not indicate whether provid-

123. Persons seeking documents im order to write articles, publisl studies, or participate in government decision-making often will suffer from the delay inherent in court remands. This unay explain why much fee-waiver case law is inade by prisoner cases. See, e.g., Rizzo v. Tyler, 438 F. Supp. 895 (S.D.N.Y. 1977).

124. See note 22 supra and accompanying text.

125. See note 23 supro and accompanying text.

126. The fourth issue, whether agencies may deny fee-waiver requests because of their asserted lack of usefulness to the requester, is discussed in note $170 \mathrm{infra}$.

127. 5 U.S.C. $\$ 552(\mathrm{a})(4)(\mathrm{A})(1976)$. 
ing documents to the press for use in "investigative reporting" benefits the public, whether nonprofit environmental groups benefit the public when they use government docuinents in administrative proceedings to attempt to change agency policy, whether scholars and authors benefit the public by illuminating historical events or conducting einpirical studies of government performance, or whether business firms benefit the general public by obtaining information about competitors' products in the hope of increasing the sales of their own products. The legislative history of the 1974 FOIA Amendments and the cases involving fee waivers and attorney's fees explain Congress's intent regarding the answers to these questions.

(a) The 1974 Senate Report. The fee-waiver provision of the 1974 Amendments to the FOIA originated in the Senate bill;: ${ }^{128}$ no such provision was in the bill that the House passed. The Senate Report ${ }^{129}$ accordingly provides the best guidance on the meaning of the publicbenefit test. The Senate relied primarily on five sources in passing the fee-waiver provision: (1) prior law on charging fees for government services, (2) a 1971 study of the FOIA prepared for the Administrative Conference, (3) a 1972 House report on the implementation of the FOIA, (4) existing agency regulations on fee waivers, and (5) discussions of public benefit in the context of attorneys' fees.

(i) Recognition of pre-1974 law. The FOIA as enacted in 1966 did not include a specific provision for either charging fees or granting waivers, but instead allowed agencies to charge "fees to the extent authorized by statute."130 The Senate Report noted that this phrase was a reference to the Independent Offices Appropriations Act of 1952 (IOAA) ${ }^{131}$ and to Circular No. A-25 of the Office of Management and Budget, first issued in 1959. 132 The IOAA allowed each agency to set fair and equitable charges for government services, requiring the agency to consider "direct and indirect cost to the Government, value

128. S. 2543, 93d Cong., 2d Sess. (1974), as amended, reprinted in 1974 SENATE REPORT, supra note 7, at 35-41, and 1975 SOURCE BOOK, supra note 3, at 187-93.

129. 1974 SENATE REPORT, supra note 7, reprinted in 1975 SOURCE BOOK, supra note 3, at 153.

130. Pub. L. No. 89-487, 80 Stat. 250 (1966) (codified at 5 U.S.C. § 552 (1970) (amended 1974)).

131. 31 U.S.C. $\S 483 a$ (1976). This act has also been called the "user fee statute," and in a prior codification was designated 5 U.S.C. $\$ 140$ (1964).

132. OMB Circular No. A-25 (Sept. 23, 1959), reprinted in Executive Privilege, Secrecy in Government, Freedom of Information: Hearings on S. 858 Before the Subcomm. on Intergovernmental Relations of the Senate Comm. on Government Operations and Subcomm. on Separation of Powers and Administrative Practice and Procedure of the Senate Comm. on the Judiciary, 93d Cong., 1st Sess., Vol. III, 468-70 app. (1973) [hereinafter cited as 1973 Senate Hearings]. 
to the recipient [which would lead toward charges], public policy or interest served [which would lead away from charges], and other pertinent facts." 133 The Office of Managenent and Budget issued Circular No. A-25 to carry out the policies of the IOAA. The transcript of the 1973 Senate hearings reprinted the circular in its entirety, and the number of the page on which the circular appears in the hearing record is specifically cited in the 1974 Senate Report. ${ }^{134}$ The circular drew the saine private-public distinction as the IOAA, stating that a charge should be imposed when a service "provides special benefits to an identifiable recipient above and beyond those which accrue to the public at large . . .."135 Examples of "special benefits" cited in the circular included patents, crop insurance, business licenses, airline route awards, safety inspection of aircraft (because it assists the beneficiary's business activity), passports, visas, airman's certificates, and special after-hours business inspections. ${ }^{136}$ On the other hand, the circular stated that charges should be waived in situations in which "the identification of the ultimate beneficiary is obscure and the service can be primarily considered as benefiting broadly the general public."137 This wording was the direct antecedent of the fee-waiver provision now found in section 552(a)(4)(A) of the FOIA. The circular gave the licensing of new biological products as one example of a public benefit ${ }^{138}$ and listed four other situations in which fees could be waived: when the cost of collecting the fees would be excessive, when free services would be a courtesy to a foreign country, when the recipient is "engaged in a nonprofit activity designed for the public safety, health, or welfare," and when "[p]ayment of the full fee by a State, local government, or nonprofit group would not be in the interest of the prograin."139

133. Act of Aug. 31, 1951, ch. 376, tit. V, § 501, 65 Stat. 290 (codified at 31 U.S.C. $\S 483 \mathrm{a}$ (1976)). The level or amount of the charges would presumably by based on the "direct and indirect cost to the Government" where value flowed entirely to the recipient; the amount would be lessened or even waived entirely where a public policy or interest was served or other "pertinent facts" presented themselves.

134. See 1974 SENATE RePORT, supra note 7, at 10, reprinted in 1975 SourCE Book, supra note 3 , at 162 .

135. OMB Circular No. A-25 (Sept. 23, 1959), quoted in 1974 SenATE RePort, supra note 7, at 10 , reprinted in 1975 SouRCE BOOK, supra note 3, at 162. The circular is reprinted in full in 1973 Senate Hearings, supra note 132, at 468-70 app.

136. OMB Circular No. A-25, \| 3a.(1), reprinted in 1973 Senate Hearings, supra note 132, at 469 app.

137. Id. \3a.(2), reprinted in 1973 Senate Hearings, supra notc 132, at 469 app.

138. Id.

139. Id. If 5b.(1)-(4), reprinted in 1973 Senate Hearings, supra note 132, at 470 app. In Aeronautical Radio, Inc. v. United States, 335 F.2d 304, 308-10 (7th Cir. 1964), the court upheld the IOAA and a Federal Communications Commission regulation interpreting the law to grant waivers of radio license fees to users "on a nonprofit basis essentially for public health, safety and 
(ii) The Administrative Conference study. In adopting the feewaiver provision, the Senate Committee also relied on a 1971 study prepared for the Administrative Conference of the United States by Professor Donald A. Gianella of Villanova University. The Committee reprinted Gianella's study in a special Source Book prepared for its inembers' use in drafting and considering the 1974 Amendments ${ }^{140}$ and relied on the Administrative Conference's recommendations. ${ }^{141} \mathrm{Gi}$ anella discussed the public-interest criterion of the IOAA and Circular No. A-25 and criticized the Attorney General's Memoranduin on the original FOIA for suggesting that self-sustaming fees be charged for providing all documents. According to Gianella, although production of soine government documents would fall within the "special berrefit" category, the circular discussed other requests that would "fall more readily" within the circular's public-benefit category. ${ }^{142}$ As examples of the latter, he asserted that "records provided to a newspaper reporter or an author concerning a matter of wide interest ultimately benefit the general public."143 Gianella would have preferred a fee and fee-waiver policy based on the expected use of documents. ${ }^{144}$ Finding, however, that uniforin application of a policy based on use would probably be unworkable, he recommended that waivers be provided to certain categories of requesters, such as those "engaged in nonprofit activities for the public safety, health and welfare," one of the categories inentioned in Circular No. A-25. ${ }^{145}$

welfare." The Supreme Court subsequently interpreted the IOAA as prohibiting charges for services that serve "public policy" or the "public interest," laying to rest the notion that the statute's instruction not to charge fees was precatory rather than mandatory. National Cable Television Ass'n v. United States, 415 U.S. 336, 340-42 (1974). A subsequent case has indicated that the preparation of environmental impact statements can be a government action that primarily benefits the general public withim the ineaning of the IOAA, at least when the statenent is not done for the benefit of a single private applicant. See Mississippi Power \& Light Co. v. NRC, 601 F.2d 223, 231 n.17 (5th Cir. 1979); $c f$. Public Serv. Co. v. Andrus, 433 F. Supp. 144 (D. Colo. 1977) (environmental impact statements can be considered as primarily benefiting the public). One inight speculate that the same rationale would justify waivers for docunnents to be used by meinbers of the public in the preparation of an environmental impact statement.

140. See Gianella, supra note 5, reprinted in 1974 SouRce BooK, supra note 5, at 296.

141. See 1974 SENATE RePORT, supra note 7, at 11, reprinted in 1975 SoURCE BooK, supra note 3 , at 163 .

142. Gianella, supra note 5, at 259, reprinted in 1974 SOURCE BOOK, supra note 5, at 338.

143. Id. Some agencies have suggested in fee-waiver appeal decisions that the news nedia might fall on the private-benefit side of the line because they are operated for profit. OMB Circular No. A-25 itself included at least one profit-making enterprise (making new biological products) as an activity that confers a public benefit, however, and the explicit references in the 1974 history to the news media, see text accompanying notes 151, 158-59 infra, make clear that a commercial news organization does qualify for a waiver if it is engaged in news-gathering.

144. Gianella, supra note 5, at 259, reprinted in 1974 SoURCE BOoK, supra note 5, at 338.

145. Id. 259-60, reprinted in 1974 SOURCE BOoK, supra note 5, at 338-39. 
(iii) Testimony before Congress. The third source to which the 1974 Senate Report referred was testimony iil both houses of Congress. In 1972 the House Committee on Government Operations concluded a long investigation into the impleinentation of the Freedoin of Information Act. In its report the committee recommended that federal agencies include ill their regulations provisions for waiver of fees when waiver would serve the public interest. ${ }^{146}$ The probleins reported in the 1972 House Report became part of the Senate Committee's grounds for proposing legislative amendments to the FOIA in 1974. The 1974 Senate Report cited the earlier House Report repeatedly, ${ }^{147}$ and the 1975 Source Book later reprimted the House Report as part of the legislative history of the 1974 Amendments. ${ }^{148}$

The 1972 House Report rang with indignation as it discussed the problems that search and copying fees had presented to a nonprofit group working on a study of air safety, a uuiversity researcher investigating pesticides, a lawyer from a nonprofit group interested in pesticide regulation, and a nonprofit transportation institute researching a public subsidies program run by the Maritime Admimistration. ${ }^{149}$ The 1974 Senate Report quoted the House Report's conclusion "that search fees and copying charges may be used by an agency to effectively deny public access to agency records," 150 making it reasonable to conclude that the Senate Committee, ill citing the House Report, had in mind the House testimony by people engaged i11 nonprofit, public-interest activities and scholarly or research projects when it recommended fee waivers for FOIA requests i11 the "public benefit." The 1974 Senate Report also discussed testimony given before the Senate Committee in 1973 on fee problems encountered by a newspaper reporter and two lawyers for a nonprofit group, ${ }^{151}$ thus adding journahsm to the kinds of publicbenefit activities contemplated by the 1974 FOIA ainendments.

(iv) Existing regulations. More evidence of the Senate Committee's intent is its statement that the public-benefit test for fee waivers is "borrowed frowl regulations in effect at the Departments of Transporta-

146. 1972 HOUSE REPORT, supra note 3, at 82, reprinted in 1975 SOURCE BOOK, supra note 3, at 89.

147. See, e.g., 1974 SenAte Report, supra note 7, at 3, reprinted in 1975 SoURCE BooK, supra note 3, at 155-56.

148. See 1975 Source BooK, supra note 3, at 1 .

149. 1972 HOUSE REPORT, supra note 3, at 58-59, reprinted in 1975 SOURCE BOOK, supra note 3 , at 65-66.

150. 1974 SenATE RePORT, supra note 7, at 11, reprinted in 1975 SOURCE Book, supra note 3, at 163 (quoting 1972 House REPORT, supra note 3, at 57).

151. 1974 SENATE REPORT, supra note 7, at 4, reprinted in 1975 SouRCE BooK, supra note 3, at 156. 
tion and Justice."152 Indeed, the public-benefit language in the Senate bill is identical in all relevant respects to the language of the Departinent of Transportation's regulation. That regulation explains what is ineant by the phrase "primarily benefiting the general public": "Exainples ... [include] reasonable requests from groups engaged in a nonprofit activity designed for the public safety, health, or welfare; schools; and students engaged in study in the field of transportation."153 Again, this supports the conclusion that nonprofit activities and educational or scholarly work were annong the types of requests the Senate had in mind when it drafted the public-benefit test.

(v) The attorneys'-fees discussion. The final and nost explicit source of information about the Senate's intent is that the Senate bill, adding a new section 552(a)(4)(E) to deal with attorneys' fees, used the same public-benefit test that is in the fee-waiver provision. ${ }^{154}$ The proposed section listed four criteria for a court to consider in deciding whether to grant attorneys' fees to a prevailing plaintiff in a FOIA case: (1) benefit to the public; (2) "commercial benefit to the coinplainant'; (3) 'the nature of the complainant's 'interest in the records sought'; and (4) 'whether the government's withholding of the records sought had a reasonable basis in law." "155 The Senate Report's discussion of the first three criteria sheds light on the types of activities the committee thought were within the public-benefit category. The first criterion would justify the award of fees "for example, where a newsinan was seeking information to be used in a publication or a public interest group was seeking information to further a project benefitting the general public, but [not when a business sought] data relating to a competitor or as a substitute for discovery" in litigation against the government. ${ }^{156}$ The commercial-benefit criterion would justify the re-

152. Id. 12, reprinted in 1975 SourCe BooK, supra note 3 , at 164 .

153. 49 C.F.R. $§ 7.87$ (c) (1974). The Justice Department regulations contained only the public-benefit language and no specific examples. 28 C.F.R. § 16.9(a) (1974). They speak of waiving fees for indigents, but not necessarily as part of the public-benefit test.

154. The proposed section 552(a)(4)(E) reads as follows:

The court inay assess against the United States reasonable attorney fees . . . In exercising its discretion under this paragraph, the court shall consider the benefit to the public, if any, ... the commercial benefit to the complainant and the nature of his interest in the records sought, and whether the government's withholding of the records sought had a reasonable basis in law.

1974 SeNATE REPORT, supra note 7, at 37-38, reprinted in 1975 SOURCE BOOK, supra note 3, at 189-90 (einphasis added).

155. Id. 19, reprinted in 1975 SOURCE Book, supra note 3, at 171 (quoting S. 2543, 93d Cong., 2d Sess. (1974)).

156. 1974 SENATE REPORT, supra note 7, at 19, reprinted in 1975 SOURCE BooK, supra note 3, at 171. 
covery of fees by an indigent or "a nonprofit public interest group," but not by "a large corporate interest (or a representative of such an interest)." 157 The discussion of the third criterion stated that the court would generally award fees if the complainant's interests were "scholarly or journalistic or public-interest oriented," but not frivolous or purely commercial. ${ }^{158}$ The report thus highlights journahists, scholars, nonprofit public-interest groups, and indigents as generally being entitled to attorneys' fees, and disapproves of attorneys' fees being awarded when documents are sought for commercial purposes. ${ }^{159}$

The rationale the report gave for distinguishing between requests that would receive assistance and requests by commercial interests was that, even without attorneys' fees, "[t]]he private self-interest motive of, and often pecuniary benefit to, the complainant will be sufficient to msure the vimdication of the rights given im the FOIA."160 This rationale apphies equally to fee waivers. If public-benefit attorneys' fees were meant to give certaim requesters an mcentive to litigate their rights under the FOIA, public-benefit fee waivers were probably meant to give these same requesters an mcentive to exercise their rights to obtain documents under the FOIA. By the same token, the intent to exclude commercial interests from satisfying the public-benefit test should apply to fee waivers as well as attorneys' fees.

(b) The Conference Report. Another source indicating legislative intent is the report of the Senate-House Conference Committee on the 1974 Amendments. ${ }^{161}$ The origmal Senate bill ${ }^{162}$ allowed agencies to

157. $1 d$.

158. Id.

159. The report specifically provided that news interests should not be considered commercial imterests. Id. See note 143 supra. The category of indigents is inentioned only in the discussion of the second criterion of the Senate's attorneys'-fees provision, the "commercial benefit" criterion, and the category of scholars is inentioned only in the discussion of the third criterion, the "nature" of the complainant's interest in information. If indigents and scholars would be eligible only under such criteria and not under the separate public-benefit criterion, one might argue that they could not use the fee-waiver provision because it contains only the "public benefit" language. This conclusion would be erroneous. The discussion of the public-benefit criterion is the one time the Senate Report uses the broad phrase "for example" before identifying newsinen and public interest groups as eligible. Other examples must also exist. Neither indigents nor scholars are akin to "coinmercial interests," the primary category of ineligible requesters. Apparently the Committee staff found it convenient for stylistic reasons to vary its examples from one paragraph to the next, while actually intending these basic groups-identified clearly in other parts of the legislative history-to be eligible for the public-benefit waiver.

160. 1974 SeNATE REPORT, supra note 7, at 19, reprinted in 1975 SouRCE BooK, supra note 3, at 171 .

161. 1974 CONFERENCE REPORT, supra note 45, reprinted in 1975 SOURCE BOOK, supra note 3.

162. S. 2543, 93d Cong., 2d Sess. (1974), as amended, reprinted in 1974 SENATE REPORT, supra note 7 , at 35-41, and 1975 Source BooK, supra note 3, at 188. The House bill included no fee- 
waive fees when the public-benefit test was satisfied and required agencies to waive fees for requests by indigents, requests for documents not found or found to be exempt, and requests in which the fee would be less than three dollars. The Conference Committee eliminated the mandatory waiver for the specific categories but changed the language of the public-benefit waiver to provide that agencies "shall" (rather than "may") waive fees when the test is satisfied. Addressing these changes, the Conference Report stated:

[T] he conference substitute retains the agency's discretionary publicinterest waiver authority but eliminates the specific categories of situations where fees should not be charged.

By eliminating the list of specific categories, the conferees do not intend to imply that agencies should actually charge fees in those categories. Rather, they felt, such inatters are properly the subject for individual agency determination in regulations implementing the Freedoin of Information law. ${ }^{163}$

That the report speaks of retaining discretionary public-interest waiver authority is puzzling, because the Conference Committee changed the key language from the discretionary "may" to the mandatory "shall." 164 Although "discretionary" could refer to the decision whether to grant a waiver-the interpretation in the Attorney General's Memorandum ${ }^{165}$-it could also refer to allowing each agency to refine the public-benefit test into ehgibility categories most suited for its particular mission. For example, the Environmental Protection Agency might focus on environmental groups, while the Commission on Civil Rights might make special provision for civil rights groups. In theory, however, the Attorney General's expansive view of the adjective "discretionary" would allow an agency to waive fees for all oil companies but charge fees for all nonprofit groups or the news media. There is nothing in the Conference Report suggesting that the conference intended to cast the public-benefit test adrift from the history already written in the House and Senate from 1972-1974, in which the test was consistently associated with requests from nonprofit groups

waiver provision. 1974 CONFERENCE REPORT, supra note 45 , at 8 , reprinted in 1975 SOURCE Book, supra note 3, at 225.

163. 1974 CONFERENCE REPORT, supra note 45, at 8, reprinted in 1975 SOURCE BOOK, supra note 3 , at 225 .

164. Compare 1974 SenATE RePort, supra note 7 , at 36, reprinted in 1975 SOURCE BooK, supra note 3, at 188, with 1974 CONFERENCE REPORT, supra note 45, at 2, reprinted in 1975 SOURCE BooK, supra note 3, at 220.

165. ATtORNEY GENERAL's 1975 MEMORANDUM, supra note 42, at 16, reprinted in 1975 SOURCE BOoK, supra note 3, at 526. 
trying to affect government policy, froin journalists, and froin scholars. ${ }^{166}$

(c) Court decisions. The few fee-waiver cases decided since the enactment of the 1974 amendments provide some guidance in determining the content of the public-benefit test. Cases dealing with the award of attorneys' fees in FOIA cases are also lelpful.

Mucl fee-waiver litigation involves prison inmates seeking docuinents relevant either to their incarceration or to their defense against pending criminal cliarges. The courts have almost uniformly lield that sucli documents were sought for the private benefit of the inmates rather than primarily for the public's benefit. ${ }^{167}$

Eudey v. $C I A^{168}$ is a good exainple of a case in which the requester satisfied the public-benefit test. In that case, the district court awarded a waiver of fees to a historian for documents to be used in her planned study on Italian and French trade unions. The Government had conceded that her study might be of public interest but asserted that most of the requested documents were exeinpt from disclosure. ${ }^{169}$ The court replied that even a single document, or the knowledge of "the absence of documents" in agency files, could "benefit the public by shedding light on the subject of plaintiff's researcli." 170 The court stated that the "central issue" is whether benefit will inure primarily to the "public at large" or to the "specific mdividual requesting the documents."171 Proper factors to consider in shedding light on that issue are the "identity of the requester" and the "nature of the information sought."172

166. See text accompanying notes 130-60 supra.

167. See Jester v. Department of Justice, No. 79-1347 (D.D.C. Aug. 24, 1979); Lyles v. Department of Justice, No. 78-1826 (D.D.C. June 6, 1979); Armstrong v. FB1, No. 78-1774 (D.D.C. Apr. 27, 1979); Butler v. IRS, No. C78-1582A (N.D. Ga. Jan. 25, 1979); Rizzo v. Tyler, 438 F. Supp. 895, 900 (S.D.N.Y. 1977); Burke v. Department of Justice, 432 F. Supp. 251 (D. Kan. 1976) (no discussion of eligibility; decision based on agency discretion), aff'd, 559 F.2d 1182 (10tl Cir. 1977); Fackelman v. Levi, 564 F.2d 734 (N.D. Ga. 1976). For a reference to an unpublished district court opinion awarding a waiver of fees, see Blue v. Bureau of Prisons, 570 F.2d 529, 531 (5th Cir. 1978).

168. 478 F. Supp. 1175 (D.D.C. 1979).

169. Id. at 1176 .

170. Id. The Eudey court's analysis is also relevant to the few agency appeal decisions that have denied fee waivers on the ground that the docuinents likely to be provided would not be useful to the requester. See Table B in text accompanyimg note 41 supra. The court reasoned that the FOIA "does not permit a consideration of how many documents will ultinately be released" and that "a simgle document may . . . substantially enrich the public domain." $478 \mathrm{~F}$. Supp. at 1177. See note 218 infra and accompanying text. This analysis leads directly to the conclusion that the statute does not permit the agency to consider how many useful facts will be inade available, as long as there is the possibility that some will be. Indeed, even the revelation of the lack of relevant facts may be useful.

171. 478 F. Supp. at 1176.

172. Id. 
The court contrasted the public benefit provided by Eudey's research with the private benefit in Rizzo v. Tyler, ${ }^{173}$ in which a fee waiver was denied a prison inmate seeking doculnents to assist in his defense against pending criminal charges. Encapsulating the distinction, the court stated: "Although many cases will not be as clear as Rizzo, the identity of the requester and whether his purpose for seeking the information is academic, journahstic, commercial or of some other public or private nature and the character of the information itself can guide the agency's determination."174 At least one government agency, the Departnent of the Interior, has read Fitzgibbon v. $C I A, 175$ a case similar to Eudey, as establishing the rule that a public-interest group such as a wilderuess or conservation organization can generally make "a prima facie case for waiver by showing that it is a nonprofit organization and that it imtends to use requested documents for purposes other than its own "immediate financial benefit." "176

In Lybarger v. Cardwell 177 the representatives of a nonprofit organization that helped persons receive Supplemental Security Inconie benefits had asked the regional Social Security office for a variety of government materials and handbooks to help the organization fulfill its duties. The organization brought suit when its request for a full waiver was denied. The issue before the Court of Appeals for the First Circuit was the extent of, rather than the entitlenient to, the waiver. ${ }^{178}$ In affirming the agency's award of only a partial waiver, the court noted

173. 438 F. Supp. 895 (S.D.N.Y. 1977).

174. 478 F. Supp. at 1177. The District Court for the District of Columbia ordered a fee waiver based on the requester's academic purpose in Fitzgibbon v. CIA, No. 76-700 (D.D.C. Jan. 10 , 1977), reprinted in 1977 Senate Hearings, supra note 8, at 822, reprinted in part in 1980 SENATE SuBCOMM. ReporT, supra note 8, at 94 n.91. In Roeder v. Federal Election Comin'n, No. 79-0216 (D.D.C. July 5, 1979), however, the same court denied, without issuing an opinion, a fee waiver to a journalist.

175. No. 76-700 (D.D.C. Jan. 10, 1977), reprinted in 1977 Senate Hearings, supra note 8, at 822. See text accompanying notes 116-20 supra.

176. Memorandum from Associate Solicitor of the Departnent of Interior to Regional Solicitor-Portland (Aug. 21, 1979) (on file with the author). The meinorandum suggested that an example of "financial benefit" to a nonprofit group might be the solicitation of new readers or members by obtaining government personnel lists. Although a court would probably agree with the Department of Interior's line-drawing, even a solicitation of new neenbers by a nonprofit group could be considered in the public interest. The purpose of soliciting new meinbers for a nonprofit group differs froin the purpose of a commercial enterprise seeking a list solely for private, profit-making solicitation. Cf. Disabled Officers Ass'n v. Rumsfeld, 428 F. Supp. 454, 458-59 (D.D.C. 1977) (holding under the privacy exemption of the FOIA, 5 U.S.C. § 552(b)(6) (1976), that in weighing the balance between the public interest in disclosure and an individual's interest in privacy, providing a list of names to a nonprofit group could be in the public interest as distinguished from providing a list "solely for purposes of private commercial solicitations").

177. 577 F.2d 764 (1st Cir. 1978).

178. The government had previously agreed to reduce fees by $75 \%$, but the plaintiff sought a waiver of all fees. 
that the FOIA vests considerable discretion in the agency in charging fees. The court also stated, however, that "it is clear that plaintiffs" request is for the good of the general public . . . ."179

The description of public and private benefit in Eudey and Lybarger matches the legislative history's discussion of the public-benefit test. ${ }^{180}$ The Eudey court's examples, quoted above, ${ }^{181}$ include two of the three basic eligible categories revealed in the legislative historyacademic and journahistic purposes. The examples also include the one basic ineligible category-commercial purpose. Lybarger provides an example of the third major ehgible category-nonprofit groups. ${ }^{182}$

Because the same public-benefit test arises in the FOIA attorneys'fees provision, ${ }^{183}$ cases interpreting that provision give further guidance on the meaning of "public benefit." The attorneys'-fees cases emphasize the same distmction between scholars, journalists, and nonprofit groups on the one hand, and commercial and purely individual interests on the other. In Lovell v. Alderete, ${ }^{184}$ for example, the Court of Appeals for the Fifth Circuit denied a prisoner's motion for attorneys' fees after FOIA litigation. The court observed that the prisoner's FOIA request for his eyeglass prescription was "not 'scholarly or journahistic or public-imterest oriented," 185 and, though it was not commercial, neither would it benefit the public, because it would "im no way add to the fund of knowledge citizens use when making vital political choices." 186 The request for the eyeglass prescription was strictly a "private matter."187 The Court of Appeals for the District of Columbia Circuit had earlier drawn the same distinction between public and pri-

179. 577 F.2d at 766 .

180. See notes 128-66 supra and accompanying text. Unfortunately, the opinions have not delved into the legislative history. Had they done so, they would be more likely to influence agency behavior.

181. See text accompanying note 174 supra.

182. See text accompanying notes 130-60 supra.

183. 5 U.S.C. $\S 552(a)(4)(E)(1976)$.

184. 630 F.2d 428 (5th Cir. 1980).

185. Id. at 433 (quoting Nationwide Bldg. Maintenance, Inc. v. Saunpson, 559 F.2d 704, 712 (D.C. Cir. 1977)).

186. 630 F.2d at 432 (citing Blue v. Bureau of Prisons, 570 F.2d 529, 534 (5th Cir. 1978)).

187. 630 F.2d at 432 . The court also applied the same tests to two other FOIA requests by the prisoner, for his parole recommendation file and for an investigative report on the Atlanta prison. It found that the latter request "would appear to have some public benefit," but that providing the investigative report to a prisoner would not likely lead to either public dissemination or a public impact. Id. at 433. But see Marschner v. Department of State, 470 F. Supp. 196, 201 (D. Conn. 1979) (attorneys' fees awarded to prisoner in successful FOIA lawsuit to obtain documents for use in own habeas corpus proceeding because the "public has an interest in the proper administration of justice in this country, and to that extent has benefited from the disclosure in this case"); Jones v. United States Secret Service, 81 F.R.D. 700 (D.D.C. 1979) (attorneys' fces awarded to prisoner because of the public imterest in keeping avenues of relief open). 
vate benefit after carefully reviewing the legislative history of the attorneys'-fees provision of the FOIA and surveying many of the decided cases under the provision. ${ }^{188}$ Indeed, the decided cases consistently put requests from scholars, journalists, and nonprofit groups on the publicbenefit side of the line.

In Goldstein v. Levi ${ }^{189}$ the District Court for the District of Columbia awarded attorneys' fees under the public-benefit test to a television producer who sought documents to use in a book and public television documentary rather than for his personal commercial benefit. ${ }^{190}$ Similarly, in Consumers Union of the United States, Inc. v. Board of Governors of the Federal Reserve System, ${ }^{191}$ the same court used the publicbenefit test to award attorneys' fees to a nonprofit consumer group that obtamed interest-rate information for various types of consumer installment loans. ${ }^{192}$ Attorneys' fees have been denied, as not meeting the public-benefit test, a plaintiff who sought her Federal Bureau of Investigation file for her personal interests, ${ }^{193}$ an agricultural group that sought records for commercial purposes, ${ }^{194}$ a taxpayer who sought Internal Revenue Service records during a fraud investigation, ${ }^{195}$ a busmess involved in defending itself in a labor dispute, ${ }^{196}$ and a person involved in a commercial dispute with a corporation. ${ }^{197}$

In summary, the fee-waiver and attorneys'-fees cases have recognized news reporting, scholarship or authorship, and activities by nonprofit organizations to be of primary benefit to the general public, while denommatimg as nonpublic the use of documents for commercial or wholly personal purposes. ${ }^{198}$ Because there has been more develop-

188. See Nationwide Bldg. Maintenance, Inc. v. Sampson, 559 F.2d 704, 710-13 (D.C. Cir. 1977). See also Fenster v. Brown, 617 F.2d 740, 744 (D.C. Cir. 1979).

189. 415 F. Supp. 303 (D.D.C. 1976).

190. Id. at 304-05; accord, Miami Herald v. Small Business Admnistration, 6 MEDIA L. REP. (BNA) 1686 (S.D. Fla. 1980) (news media granted attorneys' fees).

191. 410 F. Supp. 63 (D.D.C. 1975).

192. Id. at 64 (over $\$ 19,500$ awarded).

193. Friedman v. Kelly, No. 75-965 (D. Or. Apr. 14, 1976), discussed in Goldstein v. Levi, 415 F. Supp. 303, 304 n.4 (D.D.C. 1976). But cf. Exner v. FBl, 443 F. Supp. 1349, 1353-54 (S.D. Cal. 1978) (the court awarded attorneys' fees when the request, which was made for personal reasons, produced a public-benefit side effect), affd, 612 F.2d 1202 (9th Cir. 1980).

194. Orange County Vegetable Improvement Coop. Ass'n v. Department of Agriculture, No. 75-842 (D.D.C. Mar. 4, 1976), cited in Goldstein v. Levi, 415 F. Supp. at 304 n.4.

195. Chamberlain v. Kurtz, 589 F.2d 827, 842 (5th Cir.), cert. denied, 444 U.S. 842 (1979); see Pope v. United States, 424 F. Supp. 962 (S.D. Tex. 1977).

196. Polynesian Cultural Center v. NLRB, 600 F.2d 1327, 1330 (9th Cir. 1979) (obtaining documents in a labor dispute is a "wholly commercial" imterest, not a public benefit); accord, Werner-Continental, Inc. v. Farkas, 478 F. Supp. 815, 817 (S.D. Ohio 1979).

197. Kaye v. Burns, 411 F. Supp. 897, 904-05 (S.D.N.Y. 1976).

198. An agency may undoubtedly deny a "frivolous" claim of public benefit. Rizzo v. Tyler, 438 F. Supp. 895, 900 (S.D.N.Y. 1977). But of. 1972 HOUSE REPORT, supra note 3, at 54-55, 
ment of this distinction in the attorneys'-fees cases, the law of fee waivers would progress greatly if agencies and courts would apply the attorneys'-fees cases to resolving issues of public benefit in fee-waiver requests and litigation, ratler than acting as if the substantive meaning of the public-benefit test for fee waivers was unclear or was a matter for each agency to decide witliout congressional guidance.

2. The Issue of Cost. One of the inajor issues involving fee waivers is whether, in deciding whether to waive fees, an agency may balance the public benefit agamst the cost of providing the information. A few agency regulations explicitly state that costs may be considered 199 and a number of agency appeal decisions liave stated that costs played a role in the decision. ${ }^{200}$ The 1980 Senate Subcommittee Report, however, criticized the practice of considering costs. ${ }^{201}$

The agency regulations and appeal decisions that have relied on a cost-benefit analysis have not identified the legal grounds for their position. They probably rely either on the general notion that the FOIA's fee-waiver autliority is "discretionary" or on the fact that the statute provides for agencies to give a waiver "or reduction" of fees. ${ }^{202}$ The reference in the Conference Report to agencies' "discretionary" feewaiver authority, and the apparent conflict between that phrase and the change from the Senate bill's provision that agencies "may" waive fees to the Conference's bill's provision that agencies "shall" waive fees, have been previously analyzed. ${ }^{203}$ The question remams whether the statutory provision for a reduction of fees, as opposed to a complete waiver, was intended to allow costs to be considered. The regulations and appeal decisions that allow the balancing of cost and benefit actually use cost as the basis for denying both waivers and reductions, not merely to give reductions in lieu of waivers. But even if costs were used only to decide low mucli of a reduction or waiver to give, a problem arises in that no legislative history supports that interpretation of the "or reduction" phrase.

reprinted in 1975 SOURCE BOOK, supra note 3, at 61-62 (the use of fees to discourage "frivolous" requests is improper). In light of the legislative history, however, an agency must overcome a strong presumption of public benefit, before it can deny a waiver, if the request for the waiver comes from a reporter, scholar, or nonprofit organization. Such a request must be completely without public benefit to be designated frivolous. See text accompanying note 158 supra. In hight of the legislative history, careful court scrutimy is necessary to ensure that agencies do not deny, as frivolons, valid requests from one of these requesters.

199. See note 23 supra and accompanymg text.

200. See note 40 supra and accompanying text.

201. See 1980 SENATE SubCOMM. RePORT, supra note 8 , at 78-79.

202. See 5 U.S.C. $\$ 552(a)(4)(A)$ (1976).

203. See text accompanying notes 164-66 supra. 
Nothing in the 1974 Senate Report or in any other part of the legislative history of the 1974 amendments demonstrates any concern with the cost to the government of fee waivers. On the contrary, the legislators expressed concern about the costs to requesters of fees, citing cases of a public-imterest attorney who was told to pay $\$ 91,000$ for documents ${ }^{204}$ and of another attorney who was told to pay $\$ 20,000$ for a preliminary search. ${ }^{205}$ Furthermore, the Senate Committee made clear its intent that, despite the Independent Offices Appropriations Act's notion that government services "shall be self-sustaining to the full extent possible,"206 under the new amendments "with the provisions for waiver and reduction of fees, it is not necessary that FOIA services performed by agencies be self-sustaining."207 Similarly, when the representatives from the House and Senate met to draw up a compromise bill, their Conference report said nothing about a possible lack of selfrestraimt by requesters or about costs to the agencies. Instead, it stated: "The conferees intend that fees should not be used for the purpose of discouraging requests for information or as obstacles to disclosure of requested information."208 A fee that is an obstacle to the disclosure of requested information does not become less of an obstacle simply because the reason for imposing it is the cost to the government of providmg the documents. There is no evidence from the legislative history that cost to the government was considered a valid basis on whicl to make waiver or reduction decisions. ${ }^{209}$

204. After the House conferees accepted the Senate's proposal for public-interest fee waivers, one of the House conferees, Congressman Alexander, recounted in a floor statement the testimony given at the liearings regarding the experience of a public-interest lawyer seeking pesticide registration information from the Department of Agriculture. After pointing out that the Department refused to release the information without payment of nearly $\$ 92,000$ for a prospective one-andone-half year search, Congressman Alexander expressed concern not about the cost to the government, but about the potential cost to the requester:

I shudder to think of the amount of time, energy, and money wasted in this process.

The enactinent of these amendments to the Freedom of Information Act will put an end to the ridiculous delays, excuses, and bureaucratic runarounds whicl liave denied U.S. citizens their "right to know" and made Americans a captive of their own Government.

120 CONG. REC. 34,166 (1974), reprinted in 1975 SOURCE BoOK, supra note 3, at 387-88.

205. 1974 SENATE REPORT, supra note 7, at 11, reprinted in 1975 SouRCE BOOK, supra note 3, at 163.

206. 31 U.S.C. \& 483a (1976).

207. 1974 SENATE REPORT, supra note 7, at 11-12, reprinted in 1975 SOURCE BOOK, supra note 3 , at $163-64$.

208. 1974 CONFERENCE REPORT, supra note 45, at 7, reprinted in 1975 SOURCE BOOK, supra note 3, at 225. For a case relying on this language, see Long v. IRS, 596 F.2d 362, 367 (9th Cir. 1979) (great expense in editing documents does not justify nondisclosure), cert. denied, 446 U.S. 917 (1980).

209. An alternative to the cost interpretation of the "or reduction" phrase is that agencies can give reductions even to commercial requesters if the primary benefit from the use of certain docu- 
A number of fee-waiver cases have obliquely discussed the issue of cost. In National Consumers Congress v. Agency for International Development $^{210}$ the requesters, two nonprofit consumer orgamizations and an mdividual consumer advocate, had sought documents in order to uncover possible corruption in the rice export program. ${ }^{211}$ The agency denied their waiver request because of the magnitude of the search fees that would be required to retrieve the documents and because the documents, when located, might not reveal any evidence of corruption. ${ }^{212}$ The consumer groups apparently did not argue in court that the costs were irrelevant; the plaintiffs asserted instead that the costs would be small.213 The District Court for the District of Columbia upheld the denial, referring to the plaintiffs' request as "sweeping."214

Three years after National Consumers Congress, the same court

ments will accrue to the general public, while complete waivers are reserved for journalistic, scholarly, and nonprofit purposes. The support for this interpretation is that under the IOAA the fee cliarged for a government service (the anount of reduction from actual cost of the service) was based on factors including "public policy or interest" and "value to the recipient." 31 U.S.C. $\S 483 \mathrm{a}$ (1976). In other words, partial public benefit might lead to partial reduction. A complete exemption from fees was allowed for nonprofit activities. But commercial interests (such as companies licensing new biological products) could get such partial reductions. See text accompanyimg notes 130-39 supra. The sanie spectrun inay have been contemplated in 1974 by the drafters of section $552(a)(4)(A)$, with nonprofit groups, scliolars, and journalists placed at the total-waiver end of the spectrum, with inost commercial interests at the other end, and perlaps with indigents and some commercial interests in the middle. The Department of Justice now appears to agree with this view. See OILP's 1980 MEMORANDUM, supra note 59, at 20. The Lybarger decision did not come to this conclusion, but the court did not discuss the apparent background of the "reduction" provision in the IOAA. 577 F.2d 764 (Ist Cir. 1978). See also text accoinpanying note 178 supra.

Though it may be difficult to believe that Congress would establish a program leaving no authority for the government to base its decisions on cost, other suclt programs liave been established. For example, the Supreine Court concluded in Union Elec. Co. v. EPA, 427 U.S. 246 (1976), that Congress in the 1970 Clean Air Act Amendinents did not authorize the Environmental Protection Agency to cousider technical or economic feasibility in deciding whether to approve state implementation plans, which were designed to meet national anıbient air quahty standards. See also Bonine, The Evolution of "Technology-Forcing" in the Clean Air Act, ENVIR. REP. (BNA), Monograph No. 21 (1975) at 11-12.

210. No. 75-1209 (D.D.C. Sept. 15, 1976).

211. Id, slip op. at 6 .

212. Id. , slip op. at 18-19.

213. Id. slip op. at 19.

214. Id., slip op. at 20. National Consumers Congress can be read, lowever, as upholding the agency solely because there was no showing of public benefit rather than because of expense to the agency. In Lybarger v. Cardwell, 577 F.2d 764, 766 (1st Cir. 1978), the Court of Appeals for the First Circuit stated that the FOIA, on its face, appears to vest full discretion with an agency concerning the anrount of waiver or reduction to offer a requester. This could be read as allowing an agency to use any reason it wishes-including the expense of a coinplete waiver-for granting only a partial waiver for a public-benefit request. The court did not, however, discuss the propriety of considering the expense to the agency in deciding on an aniount of reduction. 
took an opposite position in Eudey v. CIA.$^{215}$ In that case the Central Intelligence Agency conceded that a historian's research was of public interest but denied the waiver because the search would be likely to produce little, if any, non-exempt information and would therefore be of slight benefit to the public. ${ }^{216}$ The court overturned the denial, stating that it was "based on a factor that is not controlling under the terms of the statute." 217 The court explained: "The statute does not permit a consideration of how nrany documents will ultimately be released. The court notes, moreover, that a single document may, in the present context, substantially enrich the public doniain." 218 In sum, the court held that if research is "of public interest and is significant," a decision not to grant a waiver or reduction of fees is "arbitrary and capricious."219 Fitzgibbon $v$. CIA displays a similar rationale. The court criticized an agency's statement that it felt an obligation to the public to collect fees for processing FOIA requests. The court held that "[a]ny such perceived obligation is irrelevant to the purposes of $\S 552(\mathrm{a})(4)(\mathrm{A}) . "{ }^{220}$

The most thoughtful analysis of the role of costs in decisions under the FOIA is the opinion in Long v. IRS.221 The case provides additional support for the position that the expense of processing FOIA requests is not a proper basis for denying documents to the public. In Long a private requester was willing to pay normal search and copying fees, but the government denied his FOIA request on the ground that the total cost to the government would be unreasonably high even after collecting the fees. ${ }^{222}$ The government clained it would cost $\$ 160,000$ to edit and reproduce the requested information. The Court of Appeals for the Ninth Circuit reversed the denial. The court said it believed that the actual unreinibursed cost to the Internal Revenue Service would be less, but sought to "put this inatter in perspective" by discussing "how costly the FOIA can be generally for agencies." 223 The court

215. 478 F. Supp. 1175 (D.D.C. 1979). The Eudey court did not mention National Consumers Congress in its opinion.

216. Id. at 1176-77.

217. Id. at 1177.

218. Id. The court even suggested that knowledge of "the absence of documents . . may itself benefit the public by shedding hight on the subject of Plaintiff's research." Id. If this reasoning had been applied to the request of the consumer groups in National Consumers Congress, that case would have been decided the other way.

219. Id.

220. No. 76-700, slip op. at 2 (D.D.C. Jan. 10, 1977), reprinted in 1977 Senate Hearings, supra note 8 , at 822 .

221. 596 F.2d 362 (9th Cir. 1979), cert. denied, 446 U.S. 917 (1980).

222. Certain costs, such as editing documents to delete withholdable portions, are not direct costs under section 552(a)(4)(A), and thus cannot be clarged to requesters under section 552(a)(4)(A). 596 F.2d at 366-67.

223. Id. at 367. 
noted that the Federal Bureau of Investigation estimated that its 1977 cost of complying with the FOIA was over $\$ 2.5$ million, that one FOIA request required the Department of Justice to assign 65 full-time and 21 part-time employees to process the request after a court ordered disclosure, and that despite such high expenses "Congress has not limited access under the Act." 224

Long is a particularly important case because it rejects the notion (at least for a request costing well over $\$ 100,000$ and requiring the efforts of several dozen employees) that a court or an agency has inherent authority to read a reasonable cost limitation into the Act's disclosure requirement. The court examined the legislative history and found in the Conference Report a legislative intent that agencies must absorb "substantial" costs. The court based its conclusion about legislative intent on the statement in a paragraph concerning fee waivers that asserts "that fees should not be used for the purpose of discouraging requests for information or as obstacles to disclosure of requested information."225 If this sentence shows Congress's intent as to the costs involved in Long, it necessarily shows Congress's intent as to costs involved in fee waivers. Accordingly, costs of several thousand dollars are not a proper basis for denying a fee waiver.

Another perspective outside the fee-waiver issue is the role of governunent costs in the award of attorneys' fees. The legislative history demonstrates that fee-waiver and attorneys'-fees awards are based on the same public-benefit test. ${ }^{226}$ The FOIA states that agencies "shall" grant fee waivers or reductions and that courts "may" award reasonable attorneys' fees in colmection with FOIA requests. ${ }^{227}$ Costs to the government are not a limiting factor in attorneys'-fee awards. The authority to award only "reasonable" attorneys' fees involves a consideration of the skill and efficiency with which the attorney conducts the case, not a consideration of the overall impact on the government's budget.228 Viewing the two formulations side-by-side, one inust con-

224. Id. The court indicated that a case might arise in which costs were so extreme that the request would have to be dismissed as unreasonable, but concluded that it could not find that in the case before it "the costs of editing are so extreme" as to inake the request "unreasonable as a unatter of law." Id.

225. Id. (citing 1974 CONFERENCE REPORT, supra note 45, at 7, reprinted in 1975 SouRCE BooK, supra note 3, at 225). The full paragraph is set forth at note 78 supra.

226. See text accoinpanying notes 154-60 supra.

227. Compare 5 U.S.C. § 552(a)(4)(A) (1976) with id. § 552(a)(4)(E).

228. A panel decision by the Court of Appeals for the District of Columbia Circuit, which expressed concern over the incentive that the government's "deep pocket" gives to potential litigants, tried to adopt a formula that would yield lower attorneys'-fees awards. Copeland v. Marshall, 594 F.2d 244, 250 (D.C. Cir. 1978). The panel decision was overturned in an en banc rehearing. 641 F.2d 880 (D.C. Cir. 1980). 
clude that if costs to the government play no, role in attorneys'-fees cases, those costs can play no role in fee-waiver decisions either. ${ }^{229}$

In summary, the legislative history contemplates that the government may have to bear extraordinarily high costs for all FOIA requests, including those in which a fee waiver is an element of the costs, and that Congress was much more concerned with the impact of search and duplication costs on public-benefit requesters thian witl the impact of the costs on the government agencies. Thus, the 1980 Serate Subcommittee was correct in stating that the FOIA does not permit agencies to make cost to the government a criterion by which fee-waiver or fee-reduction decisions may be made.

3. Substituting Inspection for Search and Copying. The final issue of substantive law that has arisen in the fee-waiver regulations and case-by-case decisions is whether an agency may refuse to grant a waiver solely on the ground that the requester may inspect the documents in a public reading room maintamed by the agency. Agencies have used such imspection, as a substitute for the normal process of finding requested documents and mailing them to the requester, to deny fee waivers not only to requesters located in the same city in which the documents are, but also to requesters on the other side of the continent. For example, a request the author made from Oregon for the fee-waiver appeal decisions of the Departinent of Justice, which mcluded a request for fee waiver for providing such documents, was refused because the documents were available for inspection in Washimgton, D.C. ${ }^{230}$

Refusals to grant fee waivers when documents are available for inspection can involve both a refusal to search for the specific documents requested and a refusal to provide copies of documents, unless the requester is willing and able to pay normal search and copying fees. It is not clear what legal arguments imight be marshalled in favor of such practices.

229. One may argue that the reason for ignoring expense to the government in attorneys'-fees awards is that such awards are made when the government is in some sense culpable, a factor not present in the award of fee waivers. The FOIA provides for attorneys' fees whenever a publicbenefit requester substantially prevails in court, however, with no requirement that the government acted in bad faith or unreasonably. 5 U.S.C. \& 552(a)(4)(E) (1976). See 1974 SENATE REPORT, supra note 7, at 19-20, reprinted in 1975 SOURCE BOOK, supra note 3, at 171-72. The reason for ignoring expense to the government is the same for both attorneys' fees and fee waivers, namely that each program exists to provide an incentive to public-benefit requesters.

230. Letter from Office of Privacy and Information Appeals, Department of Justice, to author (June 24, 1980). 
An agency that places file cabinets of documents in a public reading room and leaves it to the requester to find the specific documents he wants essentially has no program for searching for documents as contemplated by section 552(a)(4)(A). ${ }^{231}$ An agency that refuses to conduct searches in its public reading room and thus requires out-of-city requesters to spend additional inoney inay violate section 552(a)(4)(A)'s requirements of "uniform," "reasonable," and "standard" charges for a docuinent "search."

An agency that refuses to copy documents without charge for a person otherwise eligible for a fee waiver, simply because the docuinents may be inspected, ${ }^{232}$ violates the duplication duty imposed by section $552(\mathrm{a})(4)(\mathrm{A}) .233$

Moreover, the fee-waiver provision of section 552(a)(4)(A) states that an agency will "furnisli" requested documents. Congress used the word "furnisln" in the fee-waiver provision of the FOIA instead of words implying a inere right of inspection, even though it used words denoting inspection elsewhere in the statute for other purposes. ${ }^{234}$ The legislative history of the original FOIA also recognized the distinction between inspection and copying. The bill introduced in the Senate in 1964 provided only for inspection, but was changed by the Senate Committee to add a provision for copying:

the phrase “*** and copying ***" was added because it is frequently of little use to be able to inspeet orders or the like unless one is able to copy them for future reference. Hence the right to copy

231. "Such fees shall be limited to the reasonable standard charges for document search and duphication and provide for recovery of only the direct costs of such search and duplication." 5 U.S.C. $\$ 552(a)(4)(A)$ (1976) (emphasis added). Though such a position might be defensible as applied to persons in the same city if the file cabinets are adequately indexed under section 552(a)(2), which provides for public inspection of some documents, a requester living elsewhere in the nation-whether he seeks documents for private use or for public benefit-can be rcquircd to spend more on transportation to get to the documcnts (perhaps several hundrcd dollars) than would be the fee if the agency continued to have a search program.

232. See, e.g., 10 C.F.R. $\$ 9.14 a(g)$ (1980) (Nuclear Regulatory Commission). The regulation states that "[t]he NRC will not waive the reproduction costs for documents located or made available im the NRC Public Document Room or a local public document room in the absence of a compelling reason to do so." The preamble to the regulation states that ehigibility for a fee waiver itself is not a "compelling reason." 44 Fed. Reg. 16,000 (1979).

233. That this section speaks of duplicating indicates a duty to duplicate.

234. As the Court of Appeals for the Second Circuit stated recently in a non-fee-waiver case, Pierce \& Stevens Chem. Corp. v. United States Consumer Prod. Safety Comm'n, 585 F.2d 1382 (2d Cir. 1978): "The statute treats various types of agency information in different ways. Some 1nust be published in the Federal Register [section 552(a)(1)]; some must be made available for public inspection and copying [section 552(a)(2)]; and other reasonably described records are obtainable on request to an agency [section 552(a)(3)]." Id. at 1384. Subsection (a)(4)(A)'s waiver provision applies to both (a)(2) and (a)(3) records, because subsection (a)(4)(A) applies by its terms to all of "the provisions of this section"-that is, to the entire FOIA. 
these matters is supplemental to the right to inspect and makes the latter right meaningful. ${ }^{235}$

\section{RECOMMENDATIONS}

Part III of this article concluded that a large number of agency regulations and agency decisions on imdividual fee-waiver requests are at variance with the statute and its legislative history. It also concluded that the advice given by the Attorney General's 1975 Memorandum with regard to fee waivers was incoinplete and misleading. ${ }^{236}$ Finally, Part III concluded that several of the rulings of the courts that have heard fee-waiver cases have been reasonably consistent with the legislative history, although all have been made largely in a vacuun, without consideration of the history and legislative intent behind section 552(a)(4)(A). Court decisions on attorneys' fees have done a much better job of developing law on the "pubhc benefit" concept and drawing on the relevant legislative history.

This section makes recommendations designed to effectuate the legislative intent with respect to the issues encountered in Part III.

\section{A. Policy-Setting Through Regulations or Case-by-Case Decision- Making.}

Some agency policies are best evolved through the steady accretion of case-by-case decisions, rather than by being spelled out in generic regulations. The adjudicative process allows for experience to be

235. Senate Comm. on the Judiclary, Clarifying and Protecting the Right of the Public to Information, AND for Other Purposes, S. Rep. No. 813, 89th Cong., 1st Sess. 7 (1965), reprinted in 1974 SOURCE BooK, supra note 5, at 42. See also S. REP. No. 1219, 88th Cong., 2d Sess. 13 (1964), reprinted in 1974 SOURCE Book, supra note 5, at 98. Congress has, in another statute involving federal court transcripts, merely provided a right of inspection without charge, thereby requiring citizens to pay for any desired copies. See 28 U.S.C. § 753(b) (1976) (transcripts of federal court proceedings are "open during office hours to inspection by any person without charge") (emphasis added). When Congress further provides in section 552(a)(4)(A) for copies without charge as well as for search without charge for public-benefit requests, we may therefore conclude that it meant for the agencies to implement such a program.

236. See text accoinpanying notes $42-45$ supra. The greatest damage to proper implementation of the fee-waiver provision has probably been caused by the general tone of the inemorandum, which may have led many agencies into concluding erroneously that they need not have any fee-waiver policies at all. It bears repeating that an Attorney General's Memorandum "should be considered not a part of the legislative history," even though it nay have been prepared almost contemporaneously with the enactment of the statute. 1974 SOURCE BOOK, supra note 5, at 9 (commenting on errors in a 1967 Attorney General's Memorandum) (emplasis in original). Unfortunately, the habit of the Departinent of Justice in handing down FOIA policy pronouncements, ipse dixit, without any basis in statutory analysis or legislative history, continued in OILP's 1980 MEMORANDUM, supra note 59. This new memorandum contained 22 pages of policy direction that never cited a committee report, hearing record, or judicial opinion. These sources of law were discussed ouly in three pages in an appendix. 
gained and produces enough individual cases so that an agency can identify the important issues. ${ }^{237}$ The decision in National Consumers Congress, ${ }^{238}$ upholding an agency regulation anounting "to little more than a paraphrase of the statutory 'public interest' standard," 239 rested on the notion that in the early days of the FOIA fee-waiver provision, when agencies lacked experience in applying the statute, case-by-case decision-making was an appropriate means to evolve policy. The agencies have now had the experience of handling thousands of fee-waiver requests and deciding liundreds of fee-waiver appeals. The substantive issues are clear. Therefore, there are no longer good reasons for delaying the articulation of fee-waiver policies in agency regulations. Indeed, even soine agencies that are subdivisions of large departments feel the frustration of lack of guidance in departinental regulations. The Social Security Administration stated, in response to the Justice Department's 1979 survey, that the regulations of its parent department "simply repeat the statutory language, providing no guidance or interpretation of statutory intent. We believe that the regulations should be amplified so as to provide the guidelines needed to establish the criteria needed to reduce or waive fees." 240

The Departinent of Justice could encourage the development of more adequate regulations by taking the position that an agency cannot validly deny fee waivers for requests filed by persons associated with the fields that were apparently within the penuinbra of Congress's concern (requests by journalists, for example) unless the agency has proinulgated a regulation limiting its grant of waivers for such persons. If such leadership by the Department of Justice is lacking, agency offi-

237. Agency policies toward the regulation of potentially cancer-producing chennicals were arguably in this category in the early 1970s when the Environmental Protection Agency and the Occupational Safety and Health Adininistration engaged in adjudicatory proceedings to regulate pesticides and occupational chemicals suspected of being carcinogenic. As the issues becaine clearer, both agencies noved toward generic "cancer policies" and regulations stating the presumption that a chemical found to produce tumors in laboratory aninals posed a risk of cancer to luunans. Compare Environmental Defense Fund, Inc. v. EPA, 510 F.2d 1292 (D.C. Cir. 1975) with 40 C.F.R. § 162.11(a)(3)(ii) (1980); compare Industrial Union Dep't, AFL-CIO v. Hodgson, 499 F.2d 467 (D.C. Cir. 1974) with 29 C.F.R. $\$ 1990.143$ (b) (1980). See also Delaney Ainendinent to the Federal Food, Drug, and Cosinetics Act, 21 U.S.C. § 348(c)(3)(a) (1976).

238. No. 75-1209 (D.D.C. Sept. 15, 1976). See text accoinpanying notes 81-88 supra.

239. No. 75-1209, slip op. at 10.

240. Response on file with the author. Similarly, two-thirds of the agencies responding to a 1977 survey favored uniform, government-wide criteria for fee waivers, though not all favored binding criteria. 1980 SENATE SubCOMM. REPORT, supra note 8, at 85 . It is surprising that so many agencies recognize the desirability of having more detailed criteria, yet so few agencies have developed such guidance in their regulations. It is unknown whether this is because of uncertainty about their authority to do so or because of a lack of time to take on an additional task in a busy office. 
cials themselves can insist that their regulations be made inore specific. In the final analysis, the courts have the power to force the agencies to spell out their policies in regulations. This is essentially what the Supreme Court did im Morton v. Ruiz. ${ }^{241}$

Even if agencies promulgate regulations that spell out normal agency policy toward various types of requests, there will be a need to apply the policy to specific cases and to interpret it in borderline situations. The most important reform needed in the deciding of individual cases is a requirement that agencies give adequate explanations of their reasons for reaching particular decisions. ${ }^{242}$ Armed with an explanation, the unsuccessful requester may abandon the attempt to obtain documents, offer to the agency additional evidence of his purpose, or litigate on the basis of the request and the explanation of denial. Without such explanations, the likelihood of arbitrary and inconsistent decisions increases.

If an agency does a thorough job of spelling out entitlements or presumptions in regulations, the need for making available an indexed file of its decisions is probably not preeminent, for the decisions would no longer be the primary source of agency policy. Keeping the appeallevel decisions in an indexed file, however, would undoubtedly be useful both to requesters and to the agency persoimel deciding cases. If an agency does not establish clear policy in regulations, it must be assumed that its fee-waiver policy is the cumulative product of its decisions on individual requests-that is, its precedents. As such, all decisions must be kept in an accessible file, indexed so that the agency and potential requesters can discern the agency's policies. Permitting agencies to abstain from both categorical regulations and indexing of mdividual decisions is either an endorsement of the disfavored notion of having "secret law" or a rejection of the position that agencies should have policies on fee waivers.

\section{B. Substantive Issues.}

1. Requests Entitled to Waiver Under the Public-Benefit Test. Agencies inust use their regulations to anplify the public-benefit test by settimg forth the various categories of requests that will normally be entitled to or ineligible for fee waivers.

The purpose and legislative history of the Freedom of Information Act point to two groups of requesters whose fees should generally be

241. See text accompanying notes 68-73 supra.

242. See text accompanying notes 37-41 supra. 
waived. ${ }^{243}$ The first group consists of journalists, scholars, and authors. These persons confer a public benefit by dissemmating information to others, thereby multiplying the benefit obtained from a single release of docuinents.

The second group of requesters generally entitled to fee waivers is persons inaking requests for nonprofit purposes. Granting fee waivers to requests inade for nonprofit purposes encourages participation in the governing process by those without a direct economic motivation to do so. Circular No. A-25, the Administrative Conference study, the 1972 House Report, and the Department of Transportation regulation, which Congress relied on in enacting the fee-waiver provision, all identified requests for nonprofit purposes as deserving of fee waivers. ${ }^{244}$

There are strong reasons for also entitling indigents to fee waivers. The 1974 Senate bill imcluded a provision for mandatory fee waivers by all agencies for requests by indigents. ${ }^{245}$ The Conference Cominittee omitted the provision, noting $\mathrm{m}$ its report that it did not imtend to imply that agencies should charge fees to indigents, but that the question of waivers to indigents should be a inatter for individual agency determination. ${ }^{246}$ The purpose of the FOIA, to provide citizens with access to government records, supports granting fee waivers to indigents because, whereas denymg a non-indigent's fee-waiver request merely determines that he will bear the cost of access to agency records, denying an indigent's fee-waiver request determines that he will have no access to the agency records at all. A fee waiver for indigents would thus help advance the FOIA's basic purpose.

2. The Role of Cost. An examination of the fee-waiver provision's legislative history revealed no congressional intent that agencies be allowed to balance the cost of a document search against the public benefit provided by the search in deciding whether to waive fees. ${ }^{247} \mathrm{~A}$

243. The Department of Justice is moving in the direction of recognizing these same groups as proper recipients of fee waivers. The Attorney General's 1981 Memorandum identified "representatives of the news media or public-interest organizations and historical researchers" as categories of requesters who should "ordinarily" receive consideration and recommended that waivers be granted "generously." ATTORNEY General's 1981 MEMORANDUM, supra note 54, at 1-2.

244. See text accoinpanying notes 130-53 supra. Tax-exempt status should not be the determinate for fee-waiver eligibility. Many sinall, local groups inay not have such status because of the paperwork involved in obtaining it. In addition, tax-exeınpt status is denied groups that devote a substantial portion of their activities to influencing legislation, yet infiuencing legislation is just as likely to benefit the public as influencing an agency's regulatory or procurement policies. See note 266 infra.

245. See text accompanying note 162 supra.

246. See text accompanying note 163 supra.

247. See text accompanying notes 199-229 supra. 
balancing approach seems attractive because of the fear that fee-waiver requesters would otherwise impose high costs and unreasonable demands on agency personnel and resources. Allowing an agency to decide how many documents to give out for free, however, makes favoritism and arbitrary discrimination possible. For example, an agency might grant waivers to nonprofit groups that support its positions or to friendly journahsts, and deny waivers to those who oppose its pohicies. ${ }^{248}$ To analyze this dilemma, we must consider both the probable impact of waiving fees for volumious requests and the feasibility of imposing constraints on requesters other than the charging of fees for documents.

A recently coinpleted Department of Justice study concluded that the cost to the federal government of administering the FOIA is nearly $\$ 48$ million per year. ${ }^{249}$ Fees cover only a small portion of costs, in part because of the congressional limiting of fees to the "direct costs of . . . search and duphication."250 The government collected only $\$ 1.5$ milhon in fees in 1978 , leaving $\$ 46.5$ million uncollected. ${ }^{251}$ Because requests for fee waivers accompany only one or two percent of FOIA requests, ${ }^{252}$ current costs are largely due to requests by those obtaiming private benefit froin the FOIA-businesses, for example. The 1980 Senate Subcommittee Report recommended that "agencies should not refuse to waive fees for the mdigent, the media, scholars and non-profit groups, im order to recoup their costs due to excessive busmess use of the Act, an agency practice which has been alleged by soine requesters." 253 If the cost of the FOIA is a critical concern, it is for Congress to amend the statute to allow for greater recoupinent of costs froin pri-

248. See note 22 supra.

249. The study, conducted by questionnaire to the agencies in 1979 from the Office of Information Law and Policy (OILP), has not been pnblished. The figures are contained in Office of Information Law and Policy, Best Estimates of Costs of Administering FOIA During Calendar Year 1978 (July 17, 1979) (unpublished draft). See also Office of InfORMATION LAW \& Policy, U.S. DEP'T OF JUSTICE, FOIA UPDATE, Winter, 1980, at 1. The figures are estimates, and the General Accounting Office has in the past noted that the lack of systematic and consistent collection of cost data by agencies, and the fact that some documents would be provided even in the absence of the FOIA, are variables that "limit the validity" of the cost estimates. See GAO, Data on Privacy Act and Freedom of Information Act Provided by Federal Law Enforcement Agencies (LCD-78-119) at 2 (June 16, 1978).

250. 5 U.S.C. $\$ 552(\mathrm{a})(4)(A)$ (1976). See the discussion of Long v. IRS, 596 F.2d 362 (9th Cir. 1979), cert. denied, 446 U.S. 917 (1980), in the text accompanying notes 221-25 supra.

251. Office of Information Law and Policy, Best Estimates of Costs of Administering FOIA During Calendar Year 1978 (July 17, 1979) (Unreleased draft). See note 249 supra.

252. See Appendix I infra.

253. 1980 SENATE SUbCOMM. REPORT, supra note 8 , at 52 n.63. 
vate-benefit requesters, ${ }^{254}$ not for agencies to deny fee waivers to public-benefit requesters.

Concern about the cost of fee waivers is also directed at the implications of granting a categorical right to fee waivers regardless of amount for certain types of requests. Because the demand for free goods is unlimited, the argument goes, charging fees is necessary to discourage requesters from filing unlimited requests. Undoubtedly, soine persons would ask for inore documents than they need or could use if no costs were associated with such requests. Other persons, however, would obtain fewer documents than they need if large-volume FOIA requests could not receive fee waivers. If these persons would have used the documents to benefit the general public, the public would consequently lose these benefits, such as the benefits of thorough historical research.

To provide needed documents in public-benefit requests, while preventing such requests from imposing unlimited costs on the agencies, a coinpromise is needed. A system of partial entitleinent and partial presumption of entitlement would be a workable coinpromise. Fees for journalists, scholars, nonprofit groups, and indigents would automatically be waived up to a particular anount. This amount would be higher than the fee threshold set for cases in which the cost of collecting a fee exceeds the fee. ${ }^{255}$ Above this higher public-benefit threshold, the requester would be presuined to be entitled to a waiver, but the agency could rebut this presumption by showing that the request was not benefiting the public because it was frivolous or for private purposes. ${ }^{256}$

3. Reduction versus Waiver. A final problem is the reduction of fees. The concept of a partial reduction, rather than a coinplete waiver, appears to be an artifact remaining from the time when fee waivers were permissive under the IOAA rather than mandatory under the post-1974 FOIA. 257 The discretion to grant a reduction rather than a waiver contains a strong potential for abuse, particularly when interpreted to vest "complete" discretion in an agency. This power could

254. The danger with such a change, however, is that the financial barriers to deserving requesters who are wrongfully denied waivers would be even higher than at present.

255. Fee thresholds are discussed at note 25 supra and accompanying text.

256. If constraints besides these are needed, one possibility is to impose costs on requesters in a form other than fees. For example, a public-benefit requester might be required to spend not money but effort in inspecting documents in a convenient office if the requester asked for exceptionally voluminous amounts of material under a broad, vaguely worded request. This alternative could be abused, however, if apphed to large quantities of documents.

257. See note 209 supra and text accompanying notes 130-34 supra. 
undermine whatever fee-waiver policy is adopted. No sound, logical basis exists to guide an agency in determining the proper amount of a fee reduction. The Central Intelligence Agency's FOIA officer, discussing with the author the agency's initial pohicy of reducing fees for some requests and waiving them for others, and the agency's later tendency to waive all fees or none, said: "A request is either in the public benefit or it is not."2s8 Similarly, the Attorney General's 1981 Memorandum advised agencies that "in all appropriate cases, coinplete rather than partial waivers should be granted."259 The lack of a workable standard increases the potential for abuse and suggests that fee reductions have no place in a public-benefit fee-waiver system.

\section{Summary of Recommendations.}

The recommendations that follow are intended to reflect the precedimg discussion. Rather than being broadly-worded statements with no more specificity than the wording of the public-benefit test itself, the recommendations are quite specific.

(1) Individual agencies should amend their FOIA regulations to provide that:

(a) Nonprofit groups, journalists, scholars, authors, other noncommercial researchers, and indigents ("eligible requesters") shall always receive documents free of charge up to 2500 pages and 8 hours search time. ${ }^{260}$ Other requesters shall receive documents for free up to 250 pages and one hour search time. ${ }^{261}$

258. Telephone conversation with Acting Information and Privacy Coordinator (Mar. 28, 1980).

259. ATtORNEy GENERAL's 1981 MEMORANDUM, supra note 54, at 2.

260. This recommendation, like most of the previous discussion of what satisfies the publicbenefit test, is based on who the users of the documents are, rather than on the use to which they will put the documents (e.g., "journalists" rather than "journalistic purposes"). The Administrative Conference study discussed the possibility of a policy that would base waiver decisions on the intended use in each case, but concluded that such a policy would probably be unworkable in actual practice. See text accompanying note 145 supra. Consequently, the study suggested that fees for search and copying should be based on the identity of the requester. Gianella, supra note 5, at 259, reprinted in 1974 Source BooK, supra note 5, at 338. Nevertheless, some agencies may believe that an identity-of-requester approach leaves the door open to abuses. The recommendation could be modified (except as to indigents) to provide that an agency may deny a waiver if it determines that the requester intends to use the requested documents for wholly private purposes rather than for the purposes normally signified by the requester's status as a journahist, nonprofit group, or other eligible requester.

261. The threshold for ordinary (private-benefit) requesters has been set at 250 pages and one hour of search time because some agencies have recently set similar levels in the belief that below this point the costs of collecting and processing a payment exceed the amount of the payment. The recommendation sets the threshold for the specific categories of requesters identified throughout the legislative history at ten times that of ordinary requesters, based in part on such a ratio 
(b) Eligible requesters shall generally receive documents that they request in excess of 2500 pages and 8 hours search time unless the agency determines that the requester's purpose is commercial, financial, or clearly frivolous.

(c) Eligibility shall be considered establislied without a specific request for waiver if the agency can determine such status from the FOIA request filed.

(d) Requesters other than nonprofit groups, journahists, scholars, authors, other non-commercial researchers, or indigents, whose proposed use of documents in a specific request can be determmed primarily (not necessarily entirely) to benefit the general public, shall also be considered "eligible requesters."

(e) Any question of eligibility shall be resolved by telephone if possible and in the requester's favor when uncertamty remaims.

(f) If an agency employee decided to deny a request for a fee waiver because of the lack of eligibility of a requester, or to deny a waiver request for documents in excess of 2500 pages because of the requester's commercial, financial, or clearly frivolous purposes, a written decision shall be issued containing specific reasons for denying the fee waiver. Each argument a requester raises in writing shall be considered and answered with specificity and not merely by reciting the words of the statute, the criteria of the 1975 Attorney General's Memorandum, a hist of "factors considered," or any other conclusory formulations. The agency shall, in each case of denial, provide the requester with a copy of the agency's regulations and inform the requester of the provision for appeal.

(g) The agency shall provide for fee-waiver appeals and keep copies of appeal decisions available for the reference of agency employees and the public. The decisions shall be indexed for convenient use. The agency's regulations shall inform the public of the location of these files and copies of the files shall be provided to any fee-waiver requester free of charge upon deinand. 262

(2) Procedural steps may be imposed on voluminous requests (those portions of requests over 5000 pages) by elgible requesters if the agency is convinced that the request lacks specificity that the procedural steps can rectify. Requesters may be required to list specific docu-

found in one agency's policies. See Federal Trade Commission, Staff Bulletin 79-2 (Nov. 21, 1978).

262. One might objeet that the cost of providing such decisions could be excessive, but this article has shown that there are few appeal decisions on fee waivers, as a rule. $\ln$ any case, fee waivers are also appropriate for such documents. If the cost of providing appeal decisions became excessive, agencies could at a later time restrict this provision for automatic free copies. 
ments for that portion of a request exceeding 5000 pages, rather than obtaining a waiver under a request that simply asks for "all documents" in a certain category. The agency shall impose such a requirement only if it makes the category of documents available to the requester for inspection at a federal office of the requester's choice or pays transportation expenses for the requester to view the docuinents where they are normally located.

(3) Individual agency regulations should not include any of the following criteria, and should exphicitly tell agency employees not to adopt them, in their decision-making:

(a) A balancing test involving the costs to the agency.

(b) A requirement that inspection of documents substitute for a waiver of copying fees.

(c) A requirement for detailed written statements froin ehgible requesters. ${ }^{263}$

(d) A provision for reduction, rather than waiver, of fees for eligible requesters.

(4) The Department of Justice should adopt regulations setting forth the concepts in recommendations (1), (2), and (3) as guidelines and should refuse to defend agencies that fail to adopt binding provisions in their own regulations.

(5) The President should consider issuing an executive order requiring all federal departments and agencies to comply with the provision in recommendations (1), (2), and (3).

\section{CONCLUSION}

The Freedom of Information Act has never reached its full potential of providing "adequate information to evaluate federal programs and formulate wise policies" and of preventing government institutions from becoming "unresponsive to public needs." 264 Under current agency regulations, search fees and copying charges can "effectively deny" 265 access to agency documents by the press, scholars and historians, nonprofit public-interest groups, and indigents, though such fees

263. Some agencies, like the General Services Administration, have imposed such requirements. See 46 Fed. Reg. 8513, 8516 (1981) (to be codified in 41 C.F.R. \& 105-60.305-4). This seems inconsistent with the FOIA's purpose of making docuinents readily available to the general public, not just to those who read the Code of Federal Regulations and who can afford to correspond with the agency for several weeks. If an agency has doubts about a particular requester's eligibihty, it should use the toll-free Federal Telecommunications Systein telephone line to clear them up, as proposed in recommendation (1)(e).

264. Soucie v. David, 448 F.2d 1067, 1080 (D.C. Cir. 1971).

265. 1972 HOUSE REPORT, supra note 3, at 57, reprinted in 1975 SoURCE BooK, supra note 3, at 64 . See note 6 supra and text accompanying notes 208-09 supra. 
have hittle effect on persons with the financial incentives, notives, or ineans to obtain agency docuinents. The goals of the FOIA are frustrated when persons who want to use the Act primarily to stimulate research, public debate, political participation, or nonprofit action are discouraged froin obtaining needed information because of fees levied without adequate controls on individual employee discretion. ${ }^{266}$ As a result, the promise of "freedom" of information remains unfulfilled for many whom the original Act and the 1974 amendments were intended to help.

266. Public benefit results when information is obtained that helps citizens "in inaking vital pohitical choices." Fenster v. Brown, 617 F.2d 740, 744 (D.C. Cir. 1979) (quoting Blue v. Bureau of Prisons, 570 F.2d 529, 534 (5th Cir. 1978)). 


\section{APPENDIX I}

\section{AMOUNT OF FEE WAIVER ACTIVITY IN SELECTED AGENCIES}

\begin{tabular}{|c|c|c|c|}
\hline Agency & $\begin{array}{l}\text { Number of } \\
\text { FOIA } \\
\text { Requests }\end{array}$ & $\begin{array}{c}\text { Number of } \\
\text { Fee-Waiver } \\
\text { Requests }\end{array}$ & $\begin{array}{c}\text { Percentage of FOIA } \\
\text { Requests Involving } \\
\text { Fee-Waiver } \\
\text { Requests } \\
\% \\
\end{array}$ \\
\hline ACTION & 88 & 7 & 8 \\
\hline Central Intelligence Agency & 1,608 & 36 & 2 \\
\hline $\begin{array}{l}\text { Commerce/Nat'l Oceanic \& Atmospheric } \\
\text { Admin. }\end{array}$ & 120 & 3 & 3 \\
\hline Consumer Prod. Safety Comm'n & 4,000 & 3 & .1 \\
\hline Defense/Defense Communications Agency & 97 & 3 & 3 \\
\hline Defense/Defense Logistics Agency & 3,831 & 69 & 2 \\
\hline Equal Employınent Opportunity Comm'n & 293 & 8 & 3 \\
\hline Environmental Protection Agency & 4,223 & 81 & 2 \\
\hline Export-Import Bank & 64 & 5 & 8 \\
\hline Fed. Energy Regulatory Comm'n & 82 & 3 & 4 \\
\hline Fed. Reserve Sys. & 4,710 & 11 & .2 \\
\hline Fed. Trade Comm'n & 1,154 & 59 & 5 \\
\hline Gen. Servs. Admin. & 1,861 & 124 & 7 \\
\hline HEW/Social Security Admim. & 817 & 8 & 1 \\
\hline HEW/Food \& Drug Admin. & 32,852 & 51 & .2 \\
\hline HEW/Secretary & 492 & 39 & 8 \\
\hline HUD & 12,175 & 800 & 7 \\
\hline Nat'1 Science Foundation & 127 & 1 & 1 \\
\hline Nat'l Transp. Safety Bd. & 95 & 1 & 1 \\
\hline Nuclear Regulatory Comm'n & 644 & 120 & I9 \\
\hline $\begin{array}{l}\text { Occupational Safety \& Health Review } \\
\text { Comm'n }\end{array}$ & 30 & 4 & 13 \\
\hline Office of Management \& Budget & 135 & 7 & 5 \\
\hline Securities \& Exchange Comm'n & 1,288 & 48 & 4 \\
\hline DOT/Secretary & 300 & 13 & 4 \\
\hline USDA/Fed. Grain Inspection Serv. & 27 & 1 & 4 \\
\hline USDA/Food \& Nutrition Serv. & 165 & 12 & 7 \\
\hline USDA/Food Safety \& Quality Serv. & 378 & 24 & 6 \\
\hline USDA/Personnel & 55 & 1 & 2 \\
\hline USDA/Rural Elec. Admin. & 274 & $\underline{2}$ & 1 \\
\hline TOTAL & 71,985 & 1,544 & $2.1 \%$ \\
\hline
\end{tabular}




\section{APPENDIX II}

\section{AGENCY REGULATIONS GOVERNING FEE-WAIVER ELIGIBILITY FOR CERTAIN CLASSES OF REQUESTERS}

GOVERNMENT AGENCIES:

Regulations creating eligibility:

Commission on Civil Rights: 45 C.F.R. § 704.1(e)(2)(iii) (1979) (may waive for federal agency, foreign government, or international governmental organization); 45 C.F.R. $\$ 704.1$ (e)(2)(ii) (1979) (may waive for state or local government agency).

Department of the Army: 32 C.F.R. $\$ 518.19$ (1979) (charges may be waived for state or local government, in the imterest of the prograin).

Department of the Air Force: 32 C.F.R. $\$ 813.1(b)(2)$ (1979) (may waive where payment by state or local government "would not be consistent with traditional policy of Air Force or Federal support of the customer's endeavor").

Department of the Navy: 32 C.F.R. $\$ 701.40$ (c) (1979) (may waive for state or local government, in the interest of the program).

Defense Nuclear Agency: 32 C.F.R. $\$ 281.9(e)(1)(i i)$ (1979) (same as the Department of the Navy).

Defense Logistics Agency: 32 C.F.R. pt. 1285, app. A, Waiver of fees, 1.b (1979) (same).

Federal Communications Commission: 47 C.F.R. $\$ 0.465(c)(3)$ (1979) (the FCC has contracted out the right to make copies to a commercial firm but "has reserved the right to make copies of its records for its own use or for the use of other agencies of the U.S. Government").

Federal Energy Regulatory Commission: 18 C.F.R. § 3.8(b) (1980) (fees may be waived for government agencies).

Foreign Claims Settlement Commission: 45 C.F.R. § 503.14(d) (1979) (may waive for "government agency").

Departinent of the Interior: 43 C.F.R. $\$ 2.19$ (c)(3)(iv) (1979) (may be waived for state, local, and foreign governments and public international organizations, when to do so would be an appropriate courtesy or when "to do so will help to accomplish the work of the Departinent").

International Boundary and Water Commission: 22 C.F.R. $\S 1102.4(\mathrm{f})$ (1980) (may waive for foreign governments and other agencies).

National Credit Union Admmistration: 12 C.F.R. § 720.5(e) (1980) (may waive for a member of Congress or for a federal, state, or local governmental entity).

Small Business Administration: 13 C.F.R. $\S 102.6(d)$ (1980) (will be waived when to do so is not an undue burden and the request is from a federal, state, or local government organization).

Department of State: 45 Fcd. Reg. 58,108, 58,110-11 (1980) (to be codified in 22 C.F.R. $\$ 171.13(\mathrm{e})(2)$ ) (may waive for foreign governments and 
other governmental agencies when it would "promote the objectives of the act and of the Department").

\section{Regulations creating a presumption of entitlement:}

Department of Agriculture: 7 C.F.R. pt. 1, subpt. A, app. A, $\S 4 b(2)$ (1980) (documents shall be furnished without charge to federal agencies if quantities are "reasonable in number").

Federal Trade Commission: 16 C.F.R. $\S 4.8(c)(1)$ (1980) (determination of waiver will ordmarily not be made unless the requester is a government agency).

Nuclear Regulatory Commission: 10 C.F.R. $\$ 9.14 a(a)(2)$ (1980) (will be waived for a federal, state, local, international or foreign agency or government when to do so would be an appropriate courtesy).

Department of Treasury: 31 C.F.R. $\$ 1.6(d)(2)$ (1980) (will "normally" be waived for federal, state, or foreign governments, imternational government organizations, and local governmental agencies).

Internal Revenue Service: 26 C.F.R. $\$ 601.702(f)(2)(i i)(B)$ (1980) ("Normally, no charge will be made for providing records to Federal, state or foreign governments, international governmental organizations, or local government agencies of offices thereof').

Veteran's Administration: 38 C.F.R. $\S 1.444$ (d) (1979) (will be waived for federal, state, and local governments when VA, veterans, beneficiaries, or general public "lias a substantial interest im the purpose for which the service is requested").

\section{Regulations creating entitlement:}

Department of Commerce: 15 C.F.R. $\$ 4.9(b)(1)$ (1980) ("fees payable . . . do not apply" to federal agencies, federal courts, congressional committees or subcommittees, General Accounting Office, or Library of Congress).

Defense Commumications Agency: 32 C.F.R. $\$ 287.5$ (1979) ("Exceptions to charging fees" imclude state or local government).

Delaware River Basin Commission: 18 C.F.R. \$ 401.101(a) (1979) ("No fees shall be charged" where the requester is a congressional committee or subcommittee, the GAO, an agency of a signatory party, a court, or a state or local government).

Environmental Protection Agency: 40 C.F.R. $\$ 2.120(a)(6)$, (7) (1980) ("No charge shall be made" where the requester is a louse of Congress, a congressional committee or subcommittee ("unless the records are requested for the benefit of an individual Member of Congress or for a constituent") or a federal agency).

Food and Drug Administration: 21 C.F.R. § 20.43(a)(2), (3), (4) (1980) ("No fees shall be charged" where the requester is a congressional committee or subcommittee, the GAO, a federal agency, or a federal court); 21 C.F.R. $\$ 20.43(a)(5)(1980)$ ("No fee shall be charged" where the requester is a foreign, state, or local government or agency, when the waiver is "im the public interest" and "the objectives of the act and the agency will be promoted"). 
National Mediation Board: 29 C.F.R. $§ 1208.6($ b)(1)(ii) (1979) ("No fee shall be charged" if the requester is a congressional committee or subcommittee, a federal court, a federal agency, or the GAO).

Department of Transportation: 49 C.F.R. $\$ 7.97(b)$ (1979) ("No fee is charged" when the requester is a member of Congress requesting information "for his official use"; is a state, territory, possession, county, or municipal government or agency; is a court when the imformation will be a substitute for personal appearance by an officer or employee of the Departnent; is a foreign government or agency, or an international orgamzation).

\section{INDIGENTS:}

Regulations creating eligibility:

Some regulations state that an agency "may waive" fees for indigents:

Foreign Claims Settlentent Commission: 45 C.F.R. § 503.14(d) (1979).

National Mediation Board: 29 C.F.R. $\S 1208.6(\mathrm{~b})(2)(\mathrm{i})$ (1979) ("within the discretion of the agency").

Postal Service: 39 C.F.R. $\$ 265.8$ (1979) (may waive up to $\$ 25$ when the fee would be an "undue hardship or imconvenience [to] the requester").

Federal Hone Loan Bank Board: 12 C.F.R. § 505.4(e)(5) (1980) (authorized to waive to prevent "unnecessary hardship").

Federal Home Loan Mortgage Corporation: MC 77-3, \ E(ii) (same as above).

Interstate Commerce Commission: 49 C.F.R. $§ 1001.4$ (1979) ("undue hardship").

Other regulations require the request to have a "significant" or "strong" "public interest justification": (1979).

Federal Mediation and Conciliation Service: 29 C.F.R. $§ 1401.36(d)(1)$

Food and Drug Admmistration: 21 C.F.R. $\$ 20.43(b)$ (1980) ("verified petition").

Departnent of Labor: 29 C.F.R. § 70.67 (1980).

Other regulations further restrict ehigibility by exphicitly requiring that the request not be a burden on agency resources:

Department of Commerce: 15 C.F.R. $\S 4.9(\mathrm{~b})(4)$ (1980) (fees will not be charged for an indigent when his request has a strong public-interest justification, and "agency resources permit a waiver"; indigency is a lack of "income or resources sufficient to pay the fees involved").

Commission on Civil Rights: 45 C.F.R. $§$ 704.1(e)(3)(i) (1979) (fees will be waived for indigents when a waiver "would not constitute an unreasonable expense to the Commission"; the Commission requires a "signed stateinent" of indigency).

Department of State: 45 Fed. Reg. 58,108, 58,111 (1980) (to be codified in 22 C.F.R. \& 171.13(e)(4)).

Department of Treasury: 31 C.F.R. $\S 1.6(d)(i)$ (1980) (fees will be waived for indigents where to do so is not an "unreasonable burden"; the Treasury requires written denıonstration of indigency "under penalty of perjury" and ehigibility for food stamps or similar federal assistance). 
Small Business Administration: 13 C.F.R. $\$ 102.6(d)$ (1980) (waiver for "low income person" or "financial hardship" where the request will not impose "undue burden or expenses" on the agency).

Finally, one recently promulgated regulation implies that a requester may get a waiver if it would "meet the needs of indigent persons or relieve substantial personal hardship":

General Service Administration: 46 Fed. Reg. 8513, 8516 (1981) (to be codified in 41 C.F.R. $\S 105-60.305-4(b))$.

Regulations creating a presumption of entitlement:

Department of Energy: 10 C.F.R. $\$ 1004.9$ (a)(1)(iv) (1980) (fees shall be charged "unless" the FOIA officer "deterunines" that waiver is in the public interest; "[s]uch a determination shall ordinarily not be made unless" there will be primarily public benefit; in inaking such determination, FOIA officer "may consider" various factors, including indigency). above).

Federal Trade Commission: 16 C.F.R. $\$ 4.8(c)(1)$ (1980) (similar to

Department of Justice: 28 C.F.R. $\S 16.9$ (a) (1979) (similar to above).

\section{Regulations creating entitlement:}

Legal Services Corporation: 45 C.F.R. $§ 1602.13$ (b)-(c) (1979) (will waive all fees under $\$ 25$ for an indigent; nay waive fee over $\$ 25$ for an indigent; will not charge fees under $\$ 6.50$ for other persons). See text accoinpanying note 26 supra.

A category for indigency has been in some agency regulations since at least 1973, when the Department of Justice added a fee-waiver provision to its regulations on search and copying fees and included the provision for indigents (before passage of the 1974 amendinents to the FOIA). Compare 28 C.F.R. \& 16.9 (1973) with 28 C.F.R. $\$ 16.4$ (1970).

\section{NONPROFIT GROUPS:}

\section{Regulations creating eligibility:}

The following major departments, containing several dozen agencies, have regulations stating that fees "may" be waived "[w]here the recipient is engaged in a nonprofit activity designed for the public safety, health, or welfare": (1980).

Department of Agriculture: 7 C.F.R. pt. 1, subpt. A, app. A, § 4a(3)

Department of the Air Force: 32 C.F.R. $\$$ 813.1(b)(1) (1978) (inust be "actively promoting the public safety, health, or welfare, and the national interest").

Department of the Army: 32 C.F.R. $\$ 518.19$ (1979).

Department of the Navy: 32 C.F.R. $\$ 701.40(c)(1)(i)$ (1980).

The above provision's lineage can be traced back, through regulations of the Department of Transportation adopted in 1972, to OMB Circular No. A25 of 1959. 49 C.F.R. § 7.7(c) (1979), 37 Fed. Reg. 6317-18 (1972); OMB Cir- 
cular No. A-25, reprinted in 1973 Senate Hearings, supra note 132, at 468-70 app. See the discussion in the text accompanying notes $132-39,142$ supra.

The following state that fees "may" be waived for "nonprofit groups" and "public interest groups":

Commission on Civil Rights: 45 C.F.R. § 704.1(e)(2)(ii) (1979) ("Generdl Counsel may in his/lier discretion, waive fees" where payment by nonprofit group "would not be in the general public interest").

Environmental Protection Agency: 40 C.F.R. $§ 2.120$ (d) (1980) (fees may be waived; waiver "shall be considered (but need not necessarily be granted) in connection with each request ... from a public interest group").

Department of the Interior: 43 C.F.R. \& 2.19(c)(3)(iii) (1979) (fees may be waived for a nonprofit organization "having an official voluntary or cooperative relationship with the Department to assist the ... organization in its work with the Department").

\section{Regulations creating a presumption of entitlement:}

Department of Defense: 45 Fed. Reg. 80,502, 80,513 (1980) (to be codified in 32 C.F.R. $\$ 286.60$ (b)(3)(iv)) (waiver is "likely to be warranted" for a "nonprofit public interest group" if the subject is "known to be of wide public interest" and it "can be considered as primarily benefiting the getneral public").

Defense Nuclear Agency: 32 C.F.R. § 291.9(e)(1)(i) (1979). (1979).

Defense Logistics Agency: 32 C.F.R. pt. 1285, app. A, Waiver of fees, 1.a

Department of Energy: 10 C.F.R. $\S 1004.9(a)(1)(i i i)$ (1980) (fees will be charged unless the request is in the public interest; the agency may consider criteria including the "status of the requester as a representative of a bona fide public interest group").

Small Business Administration: 13 C.F.R. $\S 102.6$ (d) (1980) (fees "will be waived" when they impose no undue burden on the agency and wlien the waiver is for public rather than private benefit, "as will be the case with certain requests" from nonprofit groups).

Department of Transportation: 49 C.F.R. $\$ 7.97(c)$ (1979) (waiver "will" be granted if determined to be in the public interest; "[e]xamples of requests that may fall within this paragraph are reasonable requests from [nonprofit groups]") (covers several agencies).

\section{Regulations creating entitlement:}

Defense Communications Agency: 32 C.F.R. $§ 287.5$ (1979) ("Exceptions to charging fees are as follows: . . . if the requester is engaged in a nonprofit activity designed for public health, safety, or welfare . . ."). The same regulation conditions waivers to nonprofit groups on whether the group primarily benefits the general public-a more discretionary approach. The Forest Service has recently adopted a revision to its manual that grants automatic waivers up to $\$ 50$ for any nonprofit group; the Federal Trade Commission has a similar, but unpublished, pohcy granting waivers up to $\$ 100$. See note 26 supra and accompanying text. 
One other agency takes a completely opposite tact and strongly discourages the granting of waivers on the basis of nonprofit status alone:

Defense Contract Audit Agency: 32 C.F.R. $\$ 290.25$ (d)(1) (1979) ("[T]he identity or tax status of the requester . . . is not persuasive grounds for granting a waiver"); 32 C.F.R. $\$ 290.25$ (d)(2) (1979) ("Fee waivers shall be decided on case-by-case evaluation. Blanket waivers for specific individuals or organizations will not be granted"). This latter regulation has apparently been superseded by a new departinent regulation that encourages waivers for nonprofit groups. $45 \mathrm{Fed}$. Reg. 80,502, 80,513 (1980) (to be codified in 32 C.F.R. $\$ 286.60(\mathrm{~b})(3)$ (iv)). It is unknown, however, whether the agency has implemented the new department regulation and repealed its own regulation.

News MEdia

\section{Regulations creating eligibility:}

Environmental Protection Agency: 40 C.F.R. $§ 2.120$ (d) (1980) (saine as EPA's provision for public-mterest groups).

Department of the Interior: 43 C.F.R. § 2.19(c)(3)(i) (1979).

Veterans Administration: 38 C.F.R. $\S 1.555(\mathrm{f})(1)(1979)$.

The Internal Revenue Manual 1272, 1 INT. REV. MAN.-ADM. (CCH) ch. 500 , I 512(2) (1979), singles out the news inedia as a category for which the Internal Revenue Service "may" waive fees when to do so is in the "public imterest," although IRS regulations make no special mention of the news nedia.

\section{Regulations creating a presumption of entitlement:}

Department of Defense: 45 Fed. Reg. 80,502, 80,513 (1980) (to be codified in 32 C.F.R. $\$ 286.60$ (b)(3)(iii)) (waiver is "likely to be warranted" when the records are for a "news media requester" if requests are "reasonable in scope and frequency").

Defense Nuclear Agency: 32 C.F.R. $\$ 291.9$ (e)(1)(iv) (1979) ("reasonable number of records," but probably superseded by department regulation).

Defense Logistics Agency: 32 C.F.R. pt. 1285, app. A, Waiver of fees, 1.d (1979) (same as above).

Department of Energy: 10 C.F.R. $\S 1004.9$ (a)(1)(ii) (1980) (same as the department's provision for public-interest groups).

Small Busmess Administration: 13 C.F.R. $\S 102.6(d)$ (1980) (saine as the SBA's provision for nonprofit activities).

The origin of specific fee-waiver provisions for news inedia was a 1971 recommendation of the Administrative Conference. See text accompanying note 143 supra.

\section{Regulations creating entitlement:}

None.

Historians, Scholars, Authors, Universities:

Regulations creating eligibility: 
International Boundary and Water Commission: 22 C.F.R. $\S 102.4(\mathrm{f})$ (1980) ("materials may be furnished without charge . . . to . . . non profit educational organizations").

Regulations creating a presumption of entitlement:

Department of Energy: 10 C.F.R. $\S 1004.9$ (a)(1)(v) (1980) (same provision for "historian or academician" as the department's provision for publicinterest groups).

Departinent of Transportation: 49 C.F.R. § 7.97(c) (1979) (examples of public benefit might be reasonable requests from "schools" and "students engaged in study in the field of transportation").

Most of these categories of requesters would also qualify for fee waivers under categories previously discussed for nonprofit "activities" or government agencies (including state universities). No regulation specifically mentions authors, but some authors could qualify under waivers for news media. The idea of recognizing eligibility for authors can be traced back to the study prepared for the Administrative Conference in 1971, see text accompanyimg note 143 supra, whereas the recognition of schools and students first appeared in the 1972 regulations of the Departnent of Transportation.

\section{Regulations creating entitlement:}

None.

\section{OTHERS:}

In addition to the five categories histed above, three agencies have special waiver provisions for employees or forner employees to obtain their own personnel records:

Environmental Protection Agency: 40 C.F.R. § 2.120(a)(5) (1980).

Small Busmess Administration: 13 C.F.R. § 102.33(a) (1980).

Department of Transportation: 49 C.F.R. \& 7.97(b)(1) (1979).

One agency has a provision for prospective employers seeking reference data on fornier agency employees, or for similar "established business custom":

Department of the Interior: 43 C.F.R. $\S 2.19(c)(3)(v i)$ (1979).

One agency has a provision for grantees of the agency or persons performing a contract for the agency:

Environmental Protection Agency: 40 C.F.R. § 2.120(a)(8) (1980).

Two agencies nray or will waive fees for persons seeking to obtain financial benefits to which they are entitled (such as veterans, employees, or those insured by the government):

Department of the Interior: 43 C.F.R. \& 2.19(c)(3)(vii) (1979).

Department of State: 45 Fed. Reg. 58,108, 58,111 (1980) (to be codified in 22 C.F.R. § 171.13(e)(5)).

Finally, one agency has a provision for persons defending themselves in a proceeding brought by the federal government:

Sniall Business Administration: 13 C.F.R. \& 102.6(d)(4) (1980) (when the waiver is not an undue burden on agency). 


\title{
APPENDIX III
}

\section{SUMMARY OF FEE THRESHOLD POLICIES}

Table 1 lists those agencies that have no free services; Table 2 lists those agencies that charge fees only when the total search and copying cost reaches a certain threshold; Table 3 lists agencies with a fee threshold for searching; and Table 4 lists agencies with a fee threshold for copying. Not all the figures in Tables 1-4 are based on agency regulations: if an agency stated a higher figure in correspondence, that figure was used.

\section{TABLE 1}

Agencies with No Free Services

\author{
ACTION \\ Arms Control and Disarmainent Agency \\ Equal Employinent Opportunity Comm'n \\ Export-Import Bank \\ Fed. Labor Relations Auth. \\ Foreigu Claims Settlement Comm'n \\ Interstate Commerce Comm'n \\ Nat'l Credit Umion Admin. \\ Nat'l Labor Relations Bd. \\ Overseas Private Inv. Corp. \\ Railroad Retirement Bd. \\ Dep't of the Treasury \\ Int'1 Communication Agency \\ Water Resources Council
}




\section{TABLE 2}

Agencies WITH OVERALl FeE Thresholds

Agency

Fed. Deposit Ins. Corp.

Fed. Reserve Sys.

Dep't of Agriculture

Fed. Home Loan Bank Bd.

Fed. Home Loan Mortgage Corp.

Dep't of Justice

Marine Mammal Comm'n

Nat'l Aeronautics \& Space Admin.

Postal Serv.

Nat'l Mediation Bd.

Office of Personnel Management

Comm'n on Civil Rights

Community Servs. Admin.

Farin Credit Admin.

Dep't of Health, Educ. \& Welfare

Food and Drug Admim.

Small Business Admin.

Social Security Admin.

Central Intelligence Agency

Legal Servs. Corp.

Environmental Protection Agency

Fed. Trade Comm'n

Forest Serv.

Law Enforcement Assistance Admin.

Nat'l Oceanic \& Atmospheric Admin.

Nat'l Park Serv.

Nuclear Regulatory Comm'n

Rural Elec. Admin.

Dep't of Transportation

Nat'l Science Foundation

Bureau of Mines

Consumer Prod. Safety Comm'n

Dep't of Energy

Gen. Servs. Admin.

Dep't of the Interior

Dep't of State

Dep't of Defense
Amount

\begin{tabular}{ccc} 
(dollars) & & Automatic? \\
\cline { 1 - 1 } 2 & & Yes \\
2 & & No \\
3 & & No \\
3 & & No \\
3 & & No \\
3 & & Yes
\end{tabular}

Ordimarily

Ordimarily

Yes

Yes

No

No

Ordinarily

Yes

Yes

Yes

Yes

Yes

Yes

Yes

Yes

Yes

Yes

Yes

Yes

Yes

Yes

Yes

Yes

Yes

Yes

Yes

Yes

Yes

No

No

Ordinarily 
TABLE 3

Agencies with Search Fee Thresholds

\section{Agency}

Farm Credit Admin.

Fed. Mediation \& Conciliation Serv.

Comm'n of Fime Arts

Dep't of Justice

Dep't of Labor

Nat'1 Science Foundation

Council on Wage \& Price Stabilization

Administrative Conference

Environmental Proteetion Agency

Fed. Maritime Comm'n

Gen. Servs. Admm.

Dep't of Health, Educ., \& Welfare

U.S. Int'1 Trade Comm'n

Securities \& Exch. Comm'n

Social Security Admin.

Ageney for Int'1 Dev.

Fed. Communications Comm'n

Dep't of Housing \& Urban Dev.

Internal Revenue Serv.

Nat'l Security Council

Nat'1 Transp. Safety Bd.

Office of Manageinent \& Budget

Special Representative for Trade Negotiation

Veterans Admin.

Nuclear Regulatory Comm'n

Tennessee Valley Auth.

Dep't of Commerce

Postal Serv.

Civil Aeronautics Bd.

Selective Serv. Sys.
Amount

(all are automatic)

$1 / 4$ hour

"

11

11

1

"

11

$1 / 2$ hour

11

11

11

11

11

"I

1 hour

"

11

11

1

11

1

1

1

4 hours

$\$ 10$

$\$ 25$

Unlimited 
TABLE 4

Agencies with Copy Fee Thresholds

\section{Agency}

Council on Wage \& Price Stabilization

Nat'l Security Council

Office of Management \& Budget

Special Representative for Trade Negotiation

Commodity Futures Trad. Comm'n

Internal Revenue Serv.

Fed. Bureau of Investigation

U.S. Int'l Trade Comm'n

Dep't of Commerce

Administrative Conference

Occupational Safety \& Health Review Comm'n

\begin{tabular}{|c|c|}
\hline Amount & Automatic? \\
\hline 3 pages & Yes \\
\hline " & Yes \\
\hline$"$ & Yes \\
\hline 4 pages & Yes \\
\hline 10 pages & Yes \\
\hline$"$ & Yes \\
\hline 250 pages & Yes \\
\hline 50 cents & Yes \\
\hline$\$ 1$ & No \\
\hline$\$ 2$ & Yes \\
\hline$\$ 3$ & Yes \\
\hline
\end{tabular}

